\title{
Improvement Of Competitiveness In Small And Medium-Sized Enterprises
}

Kyung Jin Park, Myongji University, South Korea

Youngtae Yoo, Incheon National University, South Korea

\begin{abstract}
While SMEs (small and medium-sized enterprises) contribute much to the economy, their competitiveness compared to that of large enterprises is negligible. Periodic evaluation of the overall competitiveness of SMEs is important to determine the reasons behind their relatively low growth rate. In order to maximize the effects of support for SMEs through government policies, determining the best means of providing support and enhancing competitiveness is necessary.

Government funds or other sources of support for SMEs must be supplied according to the circumstances surrounding each enterprise. For instance, if the government invests in tangible assets, SMEs must be the target, because their size guarantees that despite their lower flexibility, competitiveness will improve. If investment is made in research and development, the firm's long-term capacity for growth must be evaluated rather than its profitability, since there is an immediate increase in costs. There are differences in the effects of investment on flexibility, immaterial capital, and the ability to compete according to the size of the firm and the number of years it has been in business; these factors must be taken into account. Also, in allocating supporting funds to SMEs, the sites at which the funds are to be used must be examined. Active use of funds in areas where SMEs cannot invest in themselves is encouraged, rather than investment in general.
\end{abstract}

Keywords: SMEs; Financial Structure; Competitiveness; Long-Term Capacity

\section{INTRODUCTION}

ince the global financial crisis of 2008, the number of workers hired by SMEs (small and medium-sized enterprises) in Korea increased by 1,954,000. This job creation in the Korean economy accounted for $85.9 \%$ of the total increase in the labor force. Furthermore, since 2008, the number of newly created SMEs increased annually at a rate of $8.9 \%$, resulting in a total of 84,697 SMEs in business as of 2014 year-end. On the other hand, the number of SMEs that went bankrupt decreased annually at a rate of $17.1 \%$ during the same time period, resulting in a cumulative total of 614 failed businesses between 2008 and 2014. Thus, 138 times more new SMEs were created than failed, indicating that the economy was active with start-up activities. However, despite the importance of SMEs in the Korean market, their overall competitiveness is constantly declining. Evaluation of this situation is crucial to identify contributing factors. In order to maximize the benefits of government policies supporting SMEs, selection of and support for SMEs must be provided so as to enhance their competitiveness. The goal of this research is to identify and analyze factors that affect the competitive performance of SMEs, after which we suggest methods to enhance their competitiveness.

The factors that make SMEs competitive can be evaluated from two perspectives - internal and external. External factors are those through which SMEs contribute to the economy as a whole. They arise from the economic and social environments that surround SMEs; they are factors over which firms have no control. Internal factors are those over which individual companies have control; firms leverage these factors to compete with each other and enhance their business performance. From the policy point of view, the competitiveness of SMEs can be considered an external factor in that it contributes to the national economy. However, internal factors also make a contribution. Therefore it is important to examine all factors related to the competitiveness of SMEs from these two perspectives. 
In this study, it was not possible to obtain data for each individual company. Therefore, aggregate data was compared with that for large companies; SME classifications were also utilized for the purposes of comparison. From this data, factors affecting the competitiveness of SMEs and details of their business environments were identified. This was followed by an in-depth analysis of the data for companies with reliable financial statements. The empirical analysis compared large companies and SMEs (externally audited companies) in order to identify competitive factors of SMEs. We also examined how such factors varied according to firm size and history. The factors unique to the competitiveness of SMEs were then analyzed as to how they affect business performance. In addition, internal factors related to competitiveness that can enhance the performance of SMEs were examined from the policy point of view. Finally, we proposed a method to enhance the competitiveness of SMEs in Korea further.

\section{DEFINITION AND STATISTICS REGARDING SMES}

The criteria for classifying SMEs vary across countries. Also, even within a single country, simple comparison is difficult because the number of employees and sales amounts differ widely across different industries. For example, in Japan, small businesses are defined as those that hire fewer than 5 employees in the retail, wholesale, and service industries. On the other hand, the requirement for the manufacturing industry is 20 . In the United States, very small businesses are defined as those that hire fewer than 20 employees, while small business hire between 20 and 99 employees, and medium-sized businesses hire between 100 and 499 employees. In Korea, as shown in Table 1, the classification is based on the number of regular employees and the amount of capital, with some differences across industries. In particular, in the manufacturing industry, SMEs are defined as businesses that hire fewer than 300 regular employees and have working capital of 8 billion KRW.

Table 1. Classification criteria for SMEs (capital, sales, and number of regular employees)

\begin{tabular}{|c|c|}
\hline Industry & Evaluation Criteria \\
\hline Manufacturing & $\begin{array}{l}\text { Fewer than } 300 \text { regular employees or capital less than } 8 \\
\text { billion KRW }\end{array}$ \\
\hline Mining & \multirow{3}{*}{$\begin{array}{l}\text { Fewer than } 300 \text { regular employees or capital less than } 3 \\
\text { billion KRW }\end{array}$} \\
\hline Construction & \\
\hline Transportation & \\
\hline $\begin{array}{l}\text { Publishing, video, broadcast communications, and information } \\
\text { services }\end{array}$ & \multirow{4}{*}{$\begin{array}{l}\text { Fewer than } 300 \text { regular employees or sales less than } 30 \\
\text { billion KRW }\end{array}$} \\
\hline Business facilities management and business support services & \\
\hline Professional, scientific, and technical activities & \\
\hline Health and social work & \\
\hline Agriculture, forestry, and fisheries & \multirow{6}{*}{$\begin{array}{l}\text { Fewer than } 200 \text { regular employees or sales less than } 20 \\
\text { billion KRW }\end{array}$} \\
\hline Electricity, gas, steam, and water supply & \\
\hline Wholesale and retail trade & \\
\hline Accommodation and restaurants & \\
\hline Finance and insurance & \\
\hline Arts, sports, and leisure industry & \\
\hline Sewage, waste management, and remediation & \multirow{3}{*}{$\begin{array}{l}\text { Fewer than } 100 \text { regular employees or sales less than } 10 \\
\text { billion KRW }\end{array}$} \\
\hline Education services & \\
\hline Repair and other services & \\
\hline Real estate and leasing & $\begin{array}{l}\text { Fewer than } 50 \text { regular employees or sales less than } 5 \text { billion } \\
\text { KRW }\end{array}$ \\
\hline
\end{tabular}

* Source: Small and Medium Businesses Administration, Statistics on SMEs, 2012

According to the Status on SMEs published in 2012 by the Central Association for SMEs, for the first decade of this millennium (2000 2010), the number of SMEs in the Korean economy increased by 414,729, creating 3,581,841 new jobs and contributing $106.4 \%$ of the total increase in employment in that time period. According to the Survey on Business across the Country published by the Korean Statistical Information Service (KOSIS), the total number of SMEs in Korea as of 2011 was 3,231,634, a 3.5\% increase from the previous year. In addition, SMEs accounted for $99.9 \%$ of businesses in Korea in the year. The total number of workers employed by SMEs is 12,626,746, accounting for $86.9 \%$ of the workforce. Also, looking at trends in the number of businesses and workers from 2003 to 2011 , SMEs make up $99.9 \%$ of all businesses in the Korean economy. Also, 86.9\% of workers in the labor force work at SMEs. Thus, SMEs account for a very significant part of the Korean economy. These statistics are similar in the manufacturing 
sector, in which the largest share of SMEs can be found in terms of number of businesses. According to KOSIS, in the manufacturing sector in Korea, the total number of SMEs as of 2011 was 113,020, a $0.99 \%$ increase from the previous year, accounting for $99.45 \%$ of all manufacturing companies in Korea. The total number of workers employed by SMEs in this sector is $2,323,449$, accounting for $76.7 \%$ of the workforce (Table 2).

Table 2. Total number of businesses and number of employees in the Korean economy / SMEs

\begin{tabular}{|c|c|c|c|c|c|c|c|c|}
\hline \multirow{2}{*}{ Year } & \multicolumn{2}{|c|}{ Total (A) } & \multicolumn{4}{|c|}{ SMEs (B) } & \multicolumn{2}{|c|}{$\begin{array}{c}\text { Ratio of SMEs to total } \\
(\mathrm{B} / \mathrm{A})\end{array}$} \\
\hline & $\begin{array}{c}\text { \# of } \\
\text { businesses }\end{array}$ & Employees & $\begin{array}{c}\text { \# of } \\
\text { businesses }\end{array}$ & $\begin{array}{l}\text { Rate of } \\
\text { change }\end{array}$ & Employees & $\begin{array}{l}\text { Rate of } \\
\text { change }\end{array}$ & $\begin{array}{c}\text { \# of } \\
\text { businesses }\end{array}$ & Employees \\
\hline 2003 & $2,939,661$ & $11,870,358$ & $2,934,897$ & & $10,308,574$ & & 99.8 & 86.8 \\
\hline 2004 & $2,927,436$ & $11,824,074$ & $2,922,533$ & $-0.42 \%$ & $10,210,629$ & $-0.95 \%$ & 99.8 & 86.4 \\
\hline 2005 & $2,867,749$ & $11,902,400$ & $2,863,583$ & $-2.02 \%$ & $10,449,182$ & $2.34 \%$ & 99.9 & 87.8 \\
\hline 2006 & $2,940,345$ & $12,234,160$ & $2,936,114$ & $2.53 \%$ & $10,677,789$ & $2.19 \%$ & 99.9 & 87.3 \\
\hline 2007 & $2,976,646$ & $12,612,692$ & $2,974,185$ & $1.30 \%$ & $11,149,134$ & $4.41 \%$ & 99.9 & 88.4 \\
\hline 2008 & $3,046,958$ & $13,070,424$ & $3,044,169$ & $2.35 \%$ & $11,467,713$ & $2.86 \%$ & 99.9 & 87.7 \\
\hline 2009 & $3,069,400$ & $13,398,497$ & $3,066,484$ & $0.73 \%$ & $11,751,022$ & $2.47 \%$ & 99.9 & 87.7 \\
\hline 2010 & $3,125,457$ & $14,135,234$ & $3,122,332$ & $1.82 \%$ & $12,262,535$ & $4.35 \%$ & 99.9 & 86.8 \\
\hline 2011 & $3,234,687$ & $14,534,230$ & $3,231,634$ & $3.50 \%$ & $12,626,746$ & $2.97 \%$ & 99.9 & 86.9 \\
\hline
\end{tabular}

* Source: Statistics Korea (http://www.index.go.kr)

\section{HYPOTHESES DEVELOPMENT}

In previous studies, productivity, profitability, and growth have been used as proxies to measure performance of SMEs. First, in terms of productivity, Fazio \& Piacentino (2010), Hall et al. (2009), Mañez et al. (2013) and Mahmood (2009) used in their studies productivity as proxy for firm performance. Fazio \& Piacentino (2010) identified that productivity of SME is influenced by geographical location and the influence weakens as the intensity of the capital increases; Hall et al. (2009) demonstrated in his study that firm size and R\&D intensity enhance productivity; Mañez et al. (2013) found that the effect of process innovation is directly related to the improvement of productivity.; Mahmood (2009) conducted research on labor productivity of SME and showed that the average labor productivity of manufacturing SMEs is rapidly increasing to surpass large enterprises.

Second, as for productivity, a number of findings can be found in which the researchers have used profitability as performance proxy of SME; they include studies carried out by (Tauringana \& Afrifa, 2013; García-Teruel \& Martínez-Solano, 2007; Salavou, 2002; Caloghiroua et al., 2004; Baños-Caballero et al., 2012; Pais \& Gama, 2015; Stephen \& Elvis, 2011). Tauringana \& Afrifa (2013) identified that using panel data analysis is important to manage account payable and account receivable to boost productivity of SME. In addition, García-Teruel \& Martínez-Solano (2007) and Pais \& Gama (2015) argued that reduction in the inventory asset and the cash conversion cycle increase profitability of a firm. Furthermore, Salavou (2002) asserted that market orientation of SME enhanced their profitability. Moreover, Caloghiroua et al. (2004) presented an outcome that shows a specific factor determining profitability of SME and large enterprises. Respectively, Stephen \& Elvis (2011) demonstrated a significant correlation between the working capital and profitability while Baños-Caballero et al. (2012) presented a significant concave not a linear relation between the two.

Lastly, through the research findings, growth is considered as an important proxy for SME performance (Moreno \& Casillas, 2007; O'Regan et al., 2006; Tan \& Tay, 1995). Moreno \& Casillas (2007) conducted an analysis on SMEs focusing on different features of high and low growing companies and explained that the factors contributing to the high growth of a firm are their size and financial resources. While O'Regan et al. (2006) presented that strategic orientation and e-commerce as the key factors determining the growth of manufacturing SMEs. Moreover, Tan \& Tay (1995) listed through a survey that the factors attributable to the growth of Singapore's SME: individual traits of the company's owner, internal control system, and the age of business.

Based on the all the finding results cited so far, the current study uses, productivity, profitability, and growth as proxies for measuring SME performance. Past literature shows that there have been a number of studies on identifying a competitive factor that determines the performance of small and medium businesses. For the past years, they argued 
that the firm size, a criteria for defining large enterprises and SMEs, is the competitive factor for SMEs. Mills \& Schumann (1985) claimed that small and medium business companies, because of their small size, provide competitive edge over large firms as it makes them flexible to the market changes. Such argument is not only contrary to the claim that after the industrial revolution, the enterprises became more productive based on economies of scale which demonstrate the effectiveness of economies of scale of 1960 70s and verify competitive edge of large businesses over small ones (Demsetz, 1973; Ravenscraft,1983). These outcomes clearly show that different internal and external business environments of those enterprises created such contradictory results. Accordingly, this paper aims to compare SMEs with large enterprises to explore how SME size affects their performances.

Furthermore, this study examines the effectiveness of flexibility as a competitive edge for SMEs since the effect of economies of scale may not be considered a competitive factor. Song (2004) states that the flexibility hypothesis is accepted by SMEs in Korea as corporate performance rises with decreasing labor equipment ratio. He verified that firms with low sales volume displayed a negative correlation between labor equipment ratio and fluctuation in sales. Lastly, investment is an important factor for an enterprise to grow into the future. If the current way of investing in the tangible capital can be replaced by investing in machinery and equipment for measuring flexibility, the long term investment for the future can be assessed based on investment in intangible capital such as R\&D cost, advertising expenses, etc, which has a substantial impact on the future development of a firm.

As noted above, flexibility can be a more significant competitive factor compared to the effect of economies of scale for small and medium businesses. In other words, analysis on SMEs may produce outcome contrary to that of the large companies, and the result may even differ among the small and medium firms. Therefore, many of the analysis conducted on those companies are not based on the linear hypothesis between the dependent and the independent variables (Baños-Caballero et al., 2012; Qian, 2002). Even among those firms defined by the national criteria as SME based on their number of employees and other standards, there exists big discrepancies in their sizes; consequently, analyzing the impact of factors such as innovative initiative and flexibility on their performances would not be viable. Against this backdrop, this paper explores SMEs' competitive factors and their correlation with performances while at the same time taking into consideration various features of different firms including their sizes, history, etc. In his research, Hall et al. (2009) argued that though innovation has a positive influence on the productivity of a company, it has an adverse impact on the productivity for a SME with a long history. He even claims that effect of economies of scale is rather meager for those SMEs. Therefore, the differences in the size and history of SMEs will produce different results. The number of employees which is the national criteria for defining SMEs are considered along with the total amount of capital to be used as one of the measuring variables for corporate size and are reflected as one of the external factors. In addition, the external factors are examined to identify whether companies with a history of innovative initiatives have a competitive edge that would influence their performances.

Hypothesis: Competitive factors that determine productivity, profitability, and growth of SMEs are influenced by their external factors.

\section{COMPETITIVENESS OF SMES COMPARED TO LARGE FIRMS}

In this section, factors influencing competitiveness and business performance of SMEs are analyzed and compared to those of large companies based on data extracted from financial statements. Since it can be difficult to obtain reliable financial statements for SMEs, business management analysis data published by the Bank of Korea was used to perform the analysis. We first examine intangible assets and financial structure, two important competitive factors that affect business performance.

\subsection{Factors Influencing Competitiveness}

Intangible assets were measured as intensity of advertising, capital, and R\&D expenditures over the period of 2007 2012 and a comparison was made between SMEs and large companies. The results of this analysis are summarized in Table 3. In the period between 2007 and 2012, advertising intensity for large companies was $0.73 \%$, while it was $0.3 \%$ for SMEs. The value for advertising intensity for large companies was therefore more than twice that of the SMEs. Capital intensity indicates how much equity is owned by a single employee. It is used in this study as a complementary indicator of the labor/equipment ratio. In the period between 2007 and 2012, the values for capital 
intensity were $769.47 \%$ for large companies and $170.74 \%$ for SMEs. Thus, capital intensity for large companies was 4.5 times greater than that of SMEs. The third indicator shows how much capital was expended for R\&D-related programs for development of new products or technologies. R\&D intensity was higher for large companies. In the period between 2009 and 2012, average R\&D intensity was $1.17 \%$ for large companies and $0.64 \%$ for SMEs, with large companies spending 1.8 times more on $R \& D$ than SMEs on average. The specific formulas for calculation of advertising intensity, capital intensity, and R\&D intensity are as follows.

$$
\begin{aligned}
& \text { Advertising intensity }=\frac{\text { Advertising Expenses }}{\text { Sales }} \\
& \text { Capital intensity }=\frac{\text { Total Assets }(\text { Average })}{\text { Number of employees }(\text { Average })} \\
& \mathrm{R} \& \mathrm{D} \text { intensity }=\frac{\text { R\&D Expenses }}{\text { Sales }}
\end{aligned}
$$

Table 3. Intangible assets

\begin{tabular}{|l|l|c|c|c|c|c|c|c|c}
\hline \multicolumn{2}{c}{ Year } & & $\mathbf{2 0 0 7}$ & $\mathbf{2 0 0 8}$ & $\mathbf{2 0 0 9}$ & $\mathbf{2 0 1 0}$ & $\mathbf{2 0 1 1}$ & $\mathbf{2 0 1 2}$ & Average \\
\hline \multirow{2}{*}{ Advertising intensity (\%) } & SMEs & - & 0.33 & 0.27 & 0.30 & 0.28 & 0.29 & 0.30 \\
\cline { 2 - 9 } & Large firms & - & 0.84 & 0.77 & 0.71 & 0.61 & 0.67 & 0.73 \\
\hline \multirow{2}{*}{ Capital intensity (\%) } & SMEs & 177.78 & 156.31 & 165.15 & 183.70 & - & - & 170.74 \\
\hline \multirow{2}{*}{ R\&D intensity (\%) } & Large firms & 653.50 & 721.49 & 839.11 & 863.78 & - & - & 769.47 \\
\cline { 2 - 9 } & SMEs & - & - & 0.62 & 0.64 & 0.64 & 0.65 & 0.64 \\
\cline { 2 - 9 } & Large firms & - & - & 1.16 & 1.19 & 1.13 & 1.21 & 1.17 \\
\hline
\end{tabular}

In order to examine financial structure for the 2009 2012 period, current ratio, leverage ratio, and interest coverage ratio were analyzed. The results are summarized in Table 4 . The results show that the current ratio for SMEs was higher than that for large companies. The average value for the current ratio of SMEs for the 2009 2012 period was $123.77 \%$, while it was $122.61 \%$ for large companies. It should be noted that the value for SMEs as of $2012 \mathrm{had}$ increased greatly over the previous year. The value for the leverage ratio of SMEs was higher than that of large companies. For the 2009 2012 period, the average leverage ratio for SMEs was $181.05 \%$, while it was $143.74 \%$ for large companies. The implication is that SMEs have a higher debt burden compared to large companies. For the 2009 2012 period, the interest coverage ratio of large companies was $306.73 \%$, while it was $205.27 \%$ for SMEs. The interest coverage ratio of large companies was therefore 1.5 times higher than that of SMEs. Moreover, while the interest coverage ratio tended to increase over time for SMEs, while it decreased for large companies. The formulas for calculation of the current ratio, leverage ratio, and interest coverage ratio are as follows.

\begin{tabular}{|c|c|c|c|c|c|c|}
\hline \multicolumn{2}{|c|}{ Year } & 2009 & 2010 & 2011 & 2012 & Average \\
\hline \multirow{2}{*}{ Current ratio $(\%)$} & SMEs & 123.08 & 123.09 & 122.81 & 126.11 & 123.77 \\
\hline & Large firms & 123.22 & 122.09 & 122.36 & 122.77 & 122.61 \\
\hline \multirow{2}{*}{ Leverage ratio (\%) } & SMEs & 188.43 & 182.23 & 179.22 & 174.31 & 181.05 \\
\hline & Large firms & 149.39 & 140.54 & 144.87 & 140.14 & 143.74 \\
\hline \multirow{2}{*}{ Interest coverage $(\%)$} & SMEs & 185.86 & 211.01 & 207.21 & 216.99 & 205.27 \\
\hline & Large firms & 270.31 & 361.29 & 316.40 & 278.90 & 306.73 \\
\hline
\end{tabular}

$$
\begin{aligned}
& \text { Current ratio }=\frac{\text { Current Assets }}{\text { Current Liability }} \\
& \text { Leverage ratio }=\frac{\text { Current Liability }+ \text { Noncurrent Liability }}{\text { Capital }} \\
& \text { Interest coverage }=\frac{\text { operating Income }}{\text { Interest Expenses }}
\end{aligned}
$$

Table 4. Capital structure 
The following conclusions were obtained when SMEs were compared to large companies in our analysis of the competitiveness of SMEs. Higher ratios were observed for large companies in terms of value added per employee and the labor equipment ratio (productivity); profit per capital and the interest coverage ratio (profit); and the rate of increase of sales and capital (growth). Also, the ratio was double in large companies for performance-enhancing competitive factors such as advertising intensity, which shows the level of investment in intangible assets and equipment, capital intensity, and R\&D intensity. These results imply that most large investments are being made by large companies. On the other hand, values for the current ratio and leverage ratio were higher for SMEs, showing that they are in better financial condition. However, on deeper analysis, these results actually indicate that it is more difficult for SMEs to receive outside investment than it is for large companies. Therefore, it is necessary to analyze and find factors that enhance business performance of SMEs. Accordingly, in addition to the above comprehensive review, an empirical analysis was conducted to identify factors that contribute to the competitiveness of SMEs. Instead of using a questionnaire survey, where different results may be obtained depending on the survey questions, we used general-purpose financial data to find factors that may improve overall competitiveness of SMEs.

\subsection{Empirical Analysis of Factors Influencing Competitiveness of SMEs and Large Firms}

There are many studies that suggest competitive factors that determine business performance of SMEs. In this paper, the following factors are discussed: productivity, profitability, and growth. The variables used to assess competitive factors vary widely by study. However, a questionnaire survey was used in most cases. By contrast, we use variables that can be measured based on financial data to determine competitive factors. In addition, studies based on questionnaire surveys are limited by sample size. Therefore, we conduct our analysis using hard data from a large sample of firms representing the competitive factors of SMEs.

\subsubsection{Sample}

The sample data used in this research was obtained from corporations and SMEs that are externally audited. Most often, SMEs are not externally audited. However, financial data of non-externally audited companies is not reliable and therefore was excluded from the analysis. In 2011 and 2012, the K-IFRS was used for external auditing of corporations, which makes it impossible to compare the financial statements of listed corporations and unlisted companies accurately. In this study, we include only externally audited SMEs with fewer than 300 employees. These are mostly unlisted companies. Therefore, in order to compare them to large companies, we chose the period from 2006 to 2010 for our study. The total sample included 23,592 observations. The winsorizing method was applied to the top and bottom $1 \%$ of the sample to prevent distortion caused by outliers.

\subsubsection{Research model}

Dependent variables for measuring firm performance (productivity, profitability, and growth) $)_{\mathrm{i}, \mathrm{t}}$

$$
=\alpha+\beta_{1} T_{A S E T} T_{\mathrm{i}, \mathrm{t}-1}+\beta_{2} L A_{\mathrm{i}, \mathrm{t}-1}+\beta_{3} A D_{\mathrm{i}, \mathrm{t}-1}+\beta_{4} R D_{\mathrm{i}, \mathrm{t}-1}+\beta_{5} L Q_{\mathrm{i}, \mathrm{t}-1}+\beta_{6} B S_{\mathrm{i}, \mathrm{t}-1}+\beta_{7} I N R T_{\mathrm{i}, \mathrm{t}-1}+\varepsilon_{\mathrm{i}}
$$

Analysis based on variables related to productivity helps identify ways to enhance performance, reduce costs, and increase profit. Financial restructuring, better investment allocation, and other efforts may lay a foundation for solid management and stable production. As a result of productivity enhancement, CEOs can distribute profits from businesses to all interested parties. In this study, two specific variables, equipment investment efficiency (INVEST) and labor productivity $(L B P R O)$, were used as representative of productivity, as follows:

$$
\text { INVEST (Equipment investment efficiency) }=\frac{\text { Economic Value Added }}{\text { Current Assets-Construction in Process }}
$$

LBPRO (Labor productivity)

$=\underline{\text { Operating Income }+ \text { Labor Expenses }+ \text { Interest Expenses }+ \text { Lease Expenses }+ \text { Tax Expenses }+ \text { Depreciation Expenses }}$

Number of employees 
For measurement of profitability, we examine managerial activities in which invested capital is used to determine returns over a given period of time and how information is provided to various stakeholders $\mathrm{w}$. We therefore utilize return on equity $(R O E)$ and return on assets $(R O A)$ variables.

$$
\begin{aligned}
& R O E(\text { Return on equity })=\frac{\text { Net Income }}{\text { Equity }} \\
& \text { ROA (Return on assets) }=\frac{\text { Net Income }}{\text { Total Assets }}
\end{aligned}
$$

The growth variable is an indicator of how the size of the company and managerial performance improved over the previous year. As independent variables we utilize asset growth (GASET) and sales growth (GSALES) to avoid multicollinearity problems.

$$
\begin{aligned}
& \text { GASET }(\text { Asset growth })=\frac{\text { Total Assets }_{t}-\text { Total Assets }_{t-1}}{\text { Total Asset }_{\text {st }-1}} \\
& \text { GSALES }(\text { Sales growth })=\frac{\text { Sales }_{t}-\text { Sales }_{t-1}}{\text { Sales }_{t-1}}
\end{aligned}
$$

As independent variables in our analysis of competitive factors that determine business performance, firm size, flexibility, and intangible assets were selected. There is a theory that firm size (TASET) is more significant than it is generally believed to be because large companies can achieve economies of scale. In particular, during the 1960s and 1970s, it was proven that large companies have an advantage over SMEs because of these economies of scale (Baumol, 1967; Demsetz, 1973; Ravenscraft, 1983).

According to Mills and Schumann (1985), SMEs have relative flexibility to respond quickly to changes in demand. In Korea, Song (2001) proved that there is negative relationship between th with e labor equipment ratio $(L A)$ and sales changes among companies with low sales. Song (2004) also reported that, among SMEs, the lower the labor equipment ratio $(L A)$ was, the better the business performance was, accepting the flexibility hypothesis. Accordingly, in order to test the flexibility hypothesis in this study, the labor equipment ratio $(L A)$ and equipment investment ratio $(A D$ and $R D$ ) were used. For companies to grow and make profits in the future, they must invest in intangible assets. The labor equipment ratio is used to measure investment in real capital, while R\&D expenditure, advertising expenditure, and other variables that may affect company growth are used to measure investment in intangible assets. In this study, advertising intensity $(A D)$ and R\&D intensity $(R D)$ were used to test the effects of investment in intangible assets on competitiveness of SMEs.

$$
\begin{aligned}
& T A S E T=\log (\text { Total assets }) \\
& L A(\text { Labor equipment ratio })=\log \left(\frac{\text { Tangible Assets }- \text { Construction work in process }}{\text { Number of employees }}\right) \\
& A D(\text { Advertising intensity })=\frac{\text { Advertising Expenses }}{\text { Sales }} \\
& R D(\mathrm{R} \& \mathrm{D} \text { intensity })=\frac{\text { Research and Development Expenses }}{\text { Sales }}
\end{aligned}
$$

In examining the relationship between the factors related to competitiveness of SMEs and their business performance, various control variables were used to control for company characteristics. These included financial variables such as the current ratio $(L Q)$, leverage ratio $(B S)$, and interest coverage ratio $(I N R T)$. The liquidity ratio, which indicates a company's ability to service short-term debt, measures the probability of the company going bankrupt. The higher the liquidity ratio, the better the financial health of the company. The leverage ratio $(B S)$, although not directly correlated with business performance, must be controlled when analyzing business performance because a high debt ratio makes interest servicing difficult, which in turn makes it difficult to raise capital. The interest coverage ratio (INRT) is an indicator of whether a company can service its interest payments. Like the current ratio, it represents a company's debt servicing ability. The lower the ratio is, the more difficult it is to service interest payments using operating income. 
On the other hand, the higher the ratio is, the lower the interest payments as a share of income, meaning that the company is in more stable financial condition. In many studies, it is a widely used variable that allows us to see a company's financial health. INRT also differs widely between SMEs as compared to large companies. Therefore, it was included as a control variable in this study.

$$
\begin{aligned}
& L Q(\text { Current ratio })=\frac{\text { Current Assets }}{\text { Current Liability }} \\
& B S(\text { Leverage ratio })=\frac{\text { Current Liability }+ \text { Noncurrent Liability }}{\text { Capital }} \\
& I N R T(\text { Interest coverage })=\frac{\text { operating Income }}{\text { Interest Expenses }}
\end{aligned}
$$

\subsubsection{Descriptive Statistics}

The descriptive statistics for our sample of externally audited companies, which includes listed companies, are summarized in Panel A, Table 5. In order to compare SMEs and large companies, the sample was divided in terms of the number of employees. Large companies are those that have more than 1,000 employees. The basic statistics for large companies are presented in Panel B, Table 5. For businesses that have 300-1,000 employees, basic statistics are presented in Panel C, Table 5. Finally, for SMEs with fewer than 300 employees, the data is presented in Panel D,

\begin{tabular}{|c|c|c|c|c|c|c|}
\hline Variables & $\mathbf{N}$ & Mean & Median & SD & Minimum & Maximum \\
\hline INVEST & 23,592 & 0.005 & 0.001 & 0.032 & -0.014 & 0.544 \\
\hline$\angle B P R O$ & 23,592 & 7.758 & 3.788 & 23.494 & -21.863 & 304.869 \\
\hline$R O E$ & 22,955 & 0.054 & 0.101 & 0.420 & -2.736 & 1.111 \\
\hline$R O A$ & 23,592 & 0.036 & 0.041 & 0.119 & -0.514 & 0.358 \\
\hline GASET & 23,114 & 1.240 & 1.121 & 0.514 & 0.525 & 5.746 \\
\hline GSALES & 22,997 & 1.321 & 1.119 & 1.180 & 0.195 & 14.089 \\
\hline$T A S E T$ & 23,592 & 24.029 & 23.760 & 1.321 & 19.646 & 27.747 \\
\hline$L A$ & 23,592 & 17.827 & 18.037 & 1.588 & 11.895 & 22.880 \\
\hline$A D$ & 23,592 & 0.006 & 0.001 & 0.016 & 0.000 & 0.126 \\
\hline$R D$ & 23,592 & 0.024 & 0.009 & 0.045 & 0.000 & 0.336 \\
\hline$L Q$ & 23,592 & 2.023 & 1.290 & 3.054 & 0.017 & 51.000 \\
\hline$B S$ & 23,592 & 0.564 & 0.572 & 0.249 & 0.032 & 1.763 \\
\hline INRT & 23,592 & 91.942 & 3.174 & 492.948 & -113.9 & 3,906 \\
\hline
\end{tabular}
Table 5.

Table 5. Descriptive Statistics

\begin{tabular}{|c|c|c|c|c|c|c|}
\hline Variables & $\mathbf{N}$ & Mean & Median & SD & Minimum & Maximum \\
\hline INVEST & 1,023 & 0.002 & 0.000 & 0.017 & -0.001 & 0.544 \\
\hline$\angle B P R O$ & 1,023 & 8.489 & 5.440 & 12.378 & -19.709 & 142.963 \\
\hline$R O E$ & 1,011 & 0.083 & 0.103 & 0.283 & -2.736 & 1.111 \\
\hline$R O A$ & 1,023 & 0.050 & 0.051 & 0.081 & -0.514 & 0.358 \\
\hline GASET & 1,005 & 1.179 & 1.113 & 0.351 & 0.525 & 5.183 \\
\hline GSALES & 1,003 & 1.211 & 1.121 & 0.672 & 0.331 & 14.089 \\
\hline TASET & 1,023 & 26.937 & 27.544 & 1.108 & 21.777 & 27.747 \\
\hline$L A$ & 1,023 & 18.244 & 18.515 & 1.706 & 11.895 & 22.392 \\
\hline$A D$ & 1,023 & 0.010 & 0.002 & 0.018 & 0.000 & 0.122 \\
\hline$R D$ & 1,023 & 0.014 & 0.004 & 0.027 & 0.000 & 0.325 \\
\hline$L Q$ & 1,023 & 1.472 & 1.196 & 1.125 & 0.063 & 10.961 \\
\hline$B S$ & 1,023 & 0.518 & 0.526 & 0.190 & 0.045 & 1.683 \\
\hline$I N R T$ & 1,023 & 212.667 & 6.029 & 773.285 & -113.902 & $3,906.000$ \\
\hline
\end{tabular}

Panel B. More than 1,000 employees

(Table 5 continued on next page) 
(Table 5 continued)

Panel C. 300 1,000 employees

\begin{tabular}{|l|r|r|r|r|r|r}
\hline \multicolumn{1}{c}{ Variables } & $\mathbf{N}$ & Mean & Median & \multicolumn{1}{c}{ SD } & \multicolumn{1}{c}{ Minimum } & \multicolumn{1}{c}{ Maximum } \\
\hline INVEST & 2,441 & 0.003 & 0.001 & 0.016 & -0.010 & 0.544 \\
\hline ROE & 2,441 & 5.433 & 3.674 & 7.327 & -21.863 & 130.883 \\
\hline ROA & 2,428 & 0.065 & 0.087 & 0.317 & -2.736 & 1.111 \\
\hline GASET & 2,441 & 0.045 & 0.042 & 0.087 & -0.514 & 0.358 \\
\hline GSALES & 2,412 & 1.212 & 1.110 & 0.458 & 0.525 & 5.746 \\
\hline TASET & 2,403 & 1.257 & 1.111 & 0.936 & 0.195 & 14.089 \\
\hline AA & 2,441 & 25.483 & 25.557 & 1.167 & 20.896 & 27.747 \\
\hline$R D$ & 2,441 & 17.829 & 18.029 & 1.601 & 11.895 & 21.600 \\
\hline$L Q$ & 2,441 & 0.011 & 0.001 & 0.025 & 0.000 & 0.126 \\
\hline$B S$ & 2,441 & 0.016 & 0.005 & 0.031 & 0.000 & 0.336 \\
\hline$I N R T$ & 2,441 & 1.810 & 1.329 & 1.761 & 0.117 & 28.669 \\
\hline
\end{tabular}

Panel C. Fewer than 300 employees

\begin{tabular}{l|c|c|c|r|r|r}
\hline \multicolumn{1}{c|}{ Variables } & $\mathbf{N}$ & Mean & Median & \multicolumn{1}{c}{ SD } & \multicolumn{1}{c}{ Minimum } & \multicolumn{1}{c}{ Maximum } \\
\hline INVEST & 20,128 & 0.006 & 0.001 & 0.034 & -0.014 & 0.544 \\
\hline LBPRO & 20,128 & 8.003 & 3.758 & 25.138 & -21.863 & 304.869 \\
\hline$R O E$ & 19,516 & 0.052 & 0.103 & 0.437 & -2.736 & 1.111 \\
\hline ROA & 20,128 & 0.034 & 0.040 & 0.123 & -0.514 & 0.358 \\
\hline GASET & 19,697 & 1.246 & 1.124 & 0.527 & 0.525 & 5.746 \\
\hline GSALES & 19,591 & 1.335 & 1.120 & 1.225 & 0.195 & 14.089 \\
\hline TASET & 20,128 & 23.705 & 23.582 & 1.013 & 19.646 & 27.747 \\
\hline LA & 20,128 & 17.806 & 18.017 & 1.577 & 11.895 & 22.880 \\
\hline$R D$ & 20,128 & 0.005 & 0.000 & 0.015 & 0.000 & 0.126 \\
\hline$L Q$ & 20,128 & 0.026 & 0.010 & 0.047 & 0.000 & 0.336 \\
\hline$B S$ & 20,128 & 2.077 & 1.292 & 3.235 & 0.017 & 51.000 \\
\hline$I N R T$ & 20,128 & 0.574 & 0.584 & 0.255 & 0.032 & 1.763 \\
\hline
\end{tabular}

\subsubsection{Results of Regression Analysis}

A regression analysis was performed in order to test if the factors that affect business performance were different for large firms and SMEs. The results are presented in Table 6. The sample data used in the model classified large and small/medium companies in such a way that the differences between them could be easily identified. In terms of the equipment investment ratio (INVEST), no significant results were observed for large companies. This finding implies that, once the company grows to a certain size, various factors that enhance competitiveness do not enhance productivity. However, for SMEs, the result showed that an increase in firm size increases productivity. In contrast, changes in the labor equipment ratio and $R \& D$ intensity ratio decreased productivity with respect to equipment investment. That is, unlike large companies, an increase in equipment investment and R\&D investment results in higher costs and decreases productivity in the short term. 
Table 6. Factors that affect productivity (INVEST)

\begin{tabular}{|c|c|c|c|c|c|c|}
\hline \multirow{2}{*}{$\begin{array}{c}\text { Invest } \\
\text { Variable }\end{array}$} & \multicolumn{2}{|c|}{$\begin{array}{l}\text { More than 1,000 employees } \\
\text { (Large Companies) }\end{array}$} & \multicolumn{2}{|c|}{$300 \sim 1,000$ employees } & \multicolumn{2}{|c|}{$\begin{array}{c}\text { Fewer than } 300 \text { employees } \\
\text { (SMEs) }\end{array}$} \\
\hline & Estimate & t-value & Estimate & t-value & Estimate & t-value \\
\hline Intercept & 0.021 & 1.10 & -0.002 & -0.23 & 0.050 & $7.70^{* * *}$ \\
\hline TASET & 0.001 & 0.97 & 0.004 & $10.20^{* * *}$ & 0.006 & $22.55^{* * *}$ \\
\hline$L A$ & -0.003 & $-4.05^{* * *}$ & -0.006 & $-18.63^{* * *}$ & -0.010 & $-59.41^{* * *}$ \\
\hline$A D$ & 0.005 & 0.16 & -0.006 & -0.47 & -0.023 & -1.52 \\
\hline$R D$ & -0.015 & -0.69 & -0.003 & -0.27 & -0.022 & $-4.59^{* * *}$ \\
\hline$L Q$ & 0.000 & -0.04 & 0.000 & -2.31 & 0.000 & $-1.92^{*}$ \\
\hline$B S$ & 0.002 & 0.57 & -0.001 & -0.67 & 0.003 & $2.62^{* * *}$ \\
\hline INRT & 0.000 & 0.81 & 0.000 & 0.97 & 0.000 & 0.31 \\
\hline \# of firms & \multicolumn{2}{|c|}{1,023} & \multicolumn{2}{|c|}{2,441} & \multicolumn{2}{|c|}{20,128} \\
\hline Adjusted $\mathrm{R}^{2}$ & \multicolumn{2}{|c|}{0.0494} & \multicolumn{2}{|c|}{0.2573} & \multicolumn{2}{|c|}{0.2099} \\
\hline
\end{tabular}

Table 7 shows that the factors affecting productivity per invested labor vary widely between large and small/medium companies. For large companies, a negative relationship is observed between firm size and labor productivity $(L B P R O)$. On the other hand, for SMEs, this relationship is positive. The implication is that, for large companies that have achieved a certain critical size, firm size is not a productivity-enhancing factor. However, for SMEs, achieving economies of scale is a way of improving labor productivity. In contrast, unlike the equipment investment ratio, advertising intensity increases labor productivity for SMEs. On the other hand, R\&D investment, like the equipment investment ratio, is negatively related to productivity. That is, $R \& D$ investment has a negative effect on productivity in the short term.

Table 7. Factors that affect productivity $(\angle B P R O)$

\begin{tabular}{|c|c|c|c|c|c|c|}
\hline \multirow{2}{*}{$\begin{array}{c}\text { LBPRO } \\
\text { Variable }\end{array}$} & \multicolumn{2}{|c|}{$\begin{array}{l}\text { More than 1,000 employees } \\
\text { (Large Companies) }\end{array}$} & \multicolumn{2}{|c|}{$300 \sim 1,000$ employees } & \multicolumn{2}{|c|}{$\begin{array}{c}\text { Fewer than } 300 \text { employees } \\
\text { (SMEs) }\end{array}$} \\
\hline & Estimate & t-value & Estimate & t-value & Estimate & t-value \\
\hline Intercept & -49.297 & $-4.29^{* * *}$ & -69.738 & $-18.13^{* * *}$ & -165.762 & $-33.97^{* * *}$ \\
\hline TASET & -1.694 & $-3.07^{* * *}$ & 2.911 & $15.21^{* * *}$ & 4.007 & $21.64^{* * *}$ \\
\hline$L A$ & 5.560 & $14.59^{* * *}$ & 0.099 & 0.66 & 4.026 & $32.47^{* * *}$ \\
\hline$A D$ & 39.574 & $2.19^{* *}$ & 30.769 & $5.62^{* * *}$ & 27.277 & $2.41^{* *}$ \\
\hline$R D$ & -22.873 & $-1.79^{*}$ & 5.598 & 1.22 & -21.830 & $-6.00^{* * *}$ \\
\hline$L Q$ & 1.158 & $3.10^{* * *}$ & -0.064 & -0.65 & -0.004 & -0.07 \\
\hline$B S$ & -1.909 & -0.91 & -1.784 & $-2.1^{* *}$ & -3.064 & $-4.24^{* * *}$ \\
\hline$I N R T$ & 0.002 & $3.96^{* * *}$ & 0.001 & $2.69^{* * *}$ & 0.002 & $6.70^{* * *}$ \\
\hline \# of firms & \multicolumn{2}{|c|}{1,023} & \multicolumn{2}{|c|}{2,441} & \multicolumn{2}{|c|}{20,128} \\
\hline Adjusted $\mathrm{R}^{2}$ & \multicolumn{2}{|c|}{0.3155} & \multicolumn{2}{|c|}{0.2331} & \multicolumn{2}{|c|}{0.1920} \\
\hline
\end{tabular}

As previously shown in our comparison of large and small/medium businesses in Korea, the variable related to business performance that varies widely between them is profitability. In Table 8, the analysis reveals that factors that affect return on equity $(R O E)$ have a negative relationship with all independent variables included in the model except for interest coverage ratio. In terms of firm size, for large companies, the greater the size, the greater the profitability. On the other hand, for SMEs, the opposite was true. As can be seen, the effects of economies of scale clearly differ according to firm size. Also, this result shows that profitability declines if equipment investment per labor is too excessive or expenditure on intangible assets such as advertising and $R \& D$ is too high. 
Table 8. Factors that affect profitability $(R O E)$

\begin{tabular}{|c|c|c|c|c|c|c|}
\hline \multirow{2}{*}{$\begin{array}{c}\text { ROE } \\
\text { Variable }\end{array}$} & \multicolumn{2}{|c|}{$\begin{array}{l}\text { More than 1,000 employees } \\
\text { (Large Companies) }\end{array}$} & \multicolumn{2}{|c|}{$300 \sim 1,000$ employees } & \multicolumn{2}{|c|}{$\begin{array}{c}\text { Fewer than } 300 \text { employees } \\
\text { (SMEs) }\end{array}$} \\
\hline & Estimate & t-value & Estimate & t-value & Estimate & t-value \\
\hline Intercept & -0.140 & -0.46 & 1.048 & $5.8^{* * *}$ & 1.867 & $20.08^{* * *}$ \\
\hline TASET & 0.047 & $3.19^{* * *}$ & -0.014 & -1.6 & -0.045 & $-12.96^{* * *}$ \\
\hline$L A$ & -0.039 & $-3.82^{* * *}$ & -0.021 & $-3.04^{* * *}$ & -0.022 & $-9.59^{* * *}$ \\
\hline$A D$ & 0.463 & 0.96 & -0.106 & -0.41 & -1.114 & $-5.01^{* * *}$ \\
\hline$R D$ & -0.517 & -1.53 & -0.948 & $-4.39^{* * *}$ & -1.886 & $-26.76^{* * *}$ \\
\hline$L Q$ & -0.016 & -1.54 & -0.023 & $-4.9^{* * *}$ & -0.005 & $-4.93^{* * *}$ \\
\hline$B S$ & -0.441 & $-7.07^{* * *}$ & -0.534 & $-12.81^{* * *}$ & -0.503 & $-30.69^{* * *}$ \\
\hline$I N R T$ & 0.000 & 0.92 & 0.000 & 1.85 & 0.000 & $3.70^{* * *}$ \\
\hline \# of firms & \multicolumn{2}{|c|}{1,011} & \multicolumn{2}{|c|}{2,428} & \multicolumn{2}{|c|}{19,516} \\
\hline Adjusted $\mathrm{R}^{2}$ & \multicolumn{2}{|c|}{0.0903} & \multicolumn{2}{|c|}{0.1050} & \multicolumn{2}{|c|}{0.0966} \\
\hline
\end{tabular}

When profitability is compared to $R O A$, the result is the same as in the model with $R O E$ as the dependent variable. Table 9 shows that all dependent variables in the model showed a negative relationship except for the interest coverage ratio.

Table 9. Factors that affect profitability $(R O A)$

\begin{tabular}{|c|c|c|c|c|c|c|}
\hline \multirow{2}{*}{$\begin{array}{c}\text { ROA } \\
\text { Variable }\end{array}$} & \multicolumn{2}{|c|}{$\begin{array}{l}\text { More than 1,000 employees } \\
\text { (Large Companies) }\end{array}$} & \multicolumn{2}{|c|}{$300 \sim 1,000$ employees } & \multicolumn{2}{|c|}{$\begin{array}{c}\text { Fewer than } 300 \text { employees } \\
\text { (SMEs) }\end{array}$} \\
\hline & Estimate & t-value & Estimate & t-value & Estimate & t-value \\
\hline Intercept & -0.084 & -1.09 & 0.403 & $8.88^{* * *}$ & 0.712 & $30.86^{* * *}$ \\
\hline TASET & 0.016 & $4.46^{* * *}$ & -0.005 & $-2.12^{* *}$ & -0.016 & $-18.68^{* * *}$ \\
\hline$L A$ & -0.010 & $-3.97^{* * *}$ & -0.009 & $-5.00^{* * *}$ & -0.007 & $-12.59^{* * *}$ \\
\hline$A D$ & 0.131 & 1.09 & -0.049 & -0.76 & -0.489 & $-9.13^{* * *}$ \\
\hline$R D$ & -0.219 & $-2.56^{* *}$ & -0.252 & $-4.66^{* * *}$ & -0.601 & $-34.91^{* * *}$ \\
\hline$L Q$ & -0.001 & -0.36 & -0.006 & $-5.27^{* * *}$ & -0.001 & $-5.31^{* * *}$ \\
\hline$B S$ & -0.192 & $-13.73^{* * *}$ & -0.203 & $-20.24^{* * *}$ & -0.206 & $-60.39^{* * *}$ \\
\hline INRT & 0.000 & $4.38^{* * *}$ & 0.000 & $7.02^{* * *}$ & 0.000 & $13.97^{* * *}$ \\
\hline \# of firms & \multicolumn{2}{|c|}{1,023} & \multicolumn{2}{|c|}{2,441} & \multicolumn{2}{|c|}{20,128} \\
\hline Adjusted $\mathrm{R}^{2}$ & \multicolumn{2}{|c|}{0.2884} & \multicolumn{2}{|c|}{0.2502} & \multicolumn{2}{|c|}{0.2503} \\
\hline
\end{tabular}

For growth-related variables, asset growth rate (GASET) and sales growth rate (GSALES) were used. In terms of the factors affected by GASET, unlike business performance, investment in intangible assets positively affected the growth of SMEs (Table 10). On the other hand, in terms of firm size, like other business performance-related variables, there was a negative relationship. That is, the smaller the firm size, the higher the growth rate for SMEs. However, for large companies, bigger companies had higher growth rates. That some large companies tend to continue growing was consistent with the conventional idea about problems associated with large conglomerates. However, although investment in intangible assets was not related to firm growth for large companies, for SMEs, both advertising and R\&D expenses had a positive relationship with growth. This finding implies that, although investment in intangible assets by SMEs may affect productivity and profitability adversely in the short term, it does help growth in the longer term. 
Table 10. Factors that affect growth (GASET)

\begin{tabular}{|c|c|c|c|c|c|c|}
\hline \multirow{2}{*}{$\begin{array}{c}\text { GASET } \\
\text { Variable }\end{array}$} & \multicolumn{2}{|c|}{$\begin{array}{l}\text { More than } 1,000 \text { employees } \\
\text { (Large Companies) }\end{array}$} & \multicolumn{2}{|c|}{$300 \sim 1,000$ employees } & \multicolumn{2}{|c|}{$\begin{array}{c}\text { Fewer than } 300 \text { employees } \\
\text { (SMEs) }\end{array}$} \\
\hline & Estimate & t-value & Estimate & t-value & Estimate & t-value \\
\hline Intercept & 1.125 & $2.97^{* * *}$ & 1.203 & $4.37^{* * *}$ & 2.322 & $20.26^{* * *}$ \\
\hline TASET & 0.046 & $2.55^{* *}$ & 0.023 & $1.71^{*}$ & -0.026 & $-6.07^{* * *}$ \\
\hline$L A$ & -0.051 & $-4.06^{* * *}$ & -0.041 & $-3.79^{* * *}$ & -0.019 & $-6.61^{* * *}$ \\
\hline$A D$ & -0.624 & -1.03 & -0.048 & -0.12 & 0.453 & $1.69^{*}$ \\
\hline$R D$ & -0.457 & -1.09 & 0.005 & 0.02 & 0.702 & $8.08^{* * *}$ \\
\hline$L Q$ & 0.058 & $4.72^{* * *}$ & 0.002 & 0.21 & 0.002 & 1.59 \\
\hline$B S$ & 0.179 & $2.61^{* * *}$ & 0.168 & $2.76^{* * *}$ & 0.127 & $7.49^{* * *}$ \\
\hline INRT & 0.000 & -1.20 & 0.000 & $1.66^{*}$ & 0.000 & $2.98^{* * *}$ \\
\hline \# of firms & \multicolumn{2}{|c|}{1,005} & \multicolumn{2}{|c|}{2,412} & \multicolumn{2}{|c|}{19,697} \\
\hline Adjusted $\mathrm{R}^{2}$ & \multicolumn{2}{|c|}{0.0989} & \multicolumn{2}{|c|}{0.0105} & \multicolumn{2}{|c|}{0.0218} \\
\hline
\end{tabular}

The results for testing of the relationship between growth and GSALES were similar to those of GASET (Table 11). However, for SMEs, investment in advertising was not related to growth. Furthermore, even for large companies, firm size was negatively related to growth. This finding implies that, although GASET is important for growth in terms of firm size, firm size actually adversely affects sales growth.

Table 11. Factors that affect growth (GSALES)

\begin{tabular}{|c|c|c|c|c|c|c|}
\hline \multirow{2}{*}{$\begin{array}{l}\text { GSALES } \\
\text { Variable }\end{array}$} & \multicolumn{2}{|c|}{$\begin{array}{l}\text { More than 1,000 employees } \\
\text { (Large Companies) }\end{array}$} & \multicolumn{2}{|c|}{$300 \sim 1,000$ employees } & \multicolumn{2}{|c|}{$\begin{array}{c}\text { Fewer than } 300 \text { employees } \\
\text { (SMEs) }\end{array}$} \\
\hline & Estimate & t-value & Estimate & t-value & Estimate & t-value \\
\hline Intercept & 3.378 & $4.39^{* * *}$ & 2.890 & $5.10^{* * *}$ & 3.585 & $13.29^{* * *}$ \\
\hline TASET & -0.110 & $-3.02^{* * *}$ & -0.014 & -0.49 & -0.062 & $-6.08^{* * *}$ \\
\hline$L A$ & 0.021 & 0.86 & -0.042 & $-1.90^{*}$ & -0.035 & $-5.16^{* * *}$ \\
\hline$A D$ & -0.218 & -0.18 & -0.063 & -0.08 & 0.898 & 1.4 \\
\hline$R D$ & -0.920 & -1.10 & -0.249 & -0.37 & 0.698 & $3.35^{* * *}$ \\
\hline$L Q$ & 0.025 & 1.01 & -0.021 & -1.40 & -0.004 & -1.19 \\
\hline$B S$ & 0.536 & $3.93^{* * *}$ & 0.032 & 0.26 & 0.290 & $7.28^{* * *}$ \\
\hline$I N R T$ & 0.000 & 0.55 & 0.000 & -0.07 & 0.000 & $1.68^{*}$ \\
\hline \# of firms & \multicolumn{2}{|c|}{1,003} & \multicolumn{2}{|c|}{2,403} & \multicolumn{2}{|c|}{19,591} \\
\hline Adjusted $\mathrm{R}^{2}$ & \multicolumn{2}{|c|}{0.0320} & \multicolumn{2}{|c|}{0.0015} & \multicolumn{2}{|c|}{0.0133} \\
\hline
\end{tabular}

\section{RESULTS}

Factors affecting competitiveness of SMEs were identified via comparison against large companies. Further analysis of these factors was conducted by comparing SMEs (externally audited firms with fewer than 300 employees) within the group. These externally audited companies were first classified in terms of the number of employees; large firms vs SMEs in the same category were then compared and their data analyzed. The results show that factors affecting business performance of SMEs differ from those of large companies. Therefore, we focused on SMEs, analyzing only factors unique to SMEs. Among the companies included in the analysis above, externally audited companies with fewer than 300 employees are classified as SMEs in Korea. They were further classified in terms of capital, number of employees, and number of years in operation for greater accuracy.

In our research model, the points of comparison are the size of capital (how much equity was invested), the number of employees (the most important criterion to determine if a company belongs to the SME category), and the number of years in operation (to see if it affects competitiveness). We classified externally audited SMEs with fewer than 300 employees into four groups; those with capital greater than 15,948 million KRW belong to the top tier and those with capital less than $3.183 \mathrm{KRW}$ belong to the bottom tier. In terms of number of employees, companies with 127-300 employees belong to the top tier and those with less than 41 belong to the bottom tier. In terms of number of years in 
operation, companies with more than 20 years in operation belong to the top tier; those with 12 years or more, the next tier; those with 8 years or more, the third tier; and those with less than 8 years, the bottom tier.

\subsection{Correlations}

A correlation analysis was performed to identify relationships among variables. The results are presented in Table 12 . Analyzing the relationship between the criteria developed to determine the characteristics of SMEs and business performance results in consistent identification of one variable, which is growth. For this variable, the results show that the higher the capital, the greater the number of employees and the higher the number of years in operation, the lower the growth rate. That is, for smaller and new small businesses, although the growth rate was higher, it gradually decreased for firms that showed minimal growth. In terms of profitability, there was a positive relationship with respect to the number of employees and a negative relationship with respect to the number of years in operation. That is, although profitability improves as the number of employees increases, it gradually declines for firms that showed minimal growth. The number of employees reflects the number of years from the previous year. Therefore, it was used to explain economies of scale. Unlike large companies, when SMEs entered a stable period after several years in operation, profitability declined.

\begin{tabular}{|c|c|c|c|c|c|c|c|c|c|c|c|c|}
\hline & LBPRO & ROE & ROA & GASET & GSALES & TASET & LA & AD & RD & LQ & BS & INRT \\
\hline INVEST & $\begin{array}{r}0.104 \\
<.0001\end{array}$ & $\begin{array}{r}0.065 \\
<.0001\end{array}$ & $\begin{array}{r}0.107 \\
<.0001\end{array}$ & $\begin{array}{l}0.007 \\
0.338\end{array}$ & $\begin{array}{r}0.030 \\
<.0001\end{array}$ & $\begin{array}{r}-0.005 \\
0.477\end{array}$ & $\begin{array}{l}-0.390 \\
<.0001\end{array}$ & $\begin{array}{r}-0.003 \\
0.683\end{array}$ & $\begin{array}{r}-0.024 \\
0.001\end{array}$ & $\begin{array}{r}0.069 \\
<.0601\end{array}$ & $\begin{array}{r}-0.068 \\
<.0001\end{array}$ & $\begin{array}{r}0.038 \\
<.0001\end{array}$ \\
\hline LBPRO & 1 & $\begin{array}{r}0.090 \\
<.0001\end{array}$ & $\begin{array}{r}0.136 \\
<.0001\end{array}$ & $\begin{array}{r}-0.004 \\
0.554\end{array}$ & $\begin{array}{r}0.028 \\
<.0001\end{array}$ & $\begin{array}{r}0.286 \\
<.0001\end{array}$ & $\begin{array}{r}0.251 \\
<.0001\end{array}$ & $\begin{array}{l}0.025 \\
0.001\end{array}$ & $\begin{array}{r}-0.081 \\
<.0001\end{array}$ & $\begin{array}{l}0.002 \\
0.779\end{array}$ & $\begin{array}{r}-0.058 \\
<.0001\end{array}$ & $\begin{array}{r}0.065 \\
<.0001\end{array}$ \\
\hline ROE & & 1 & $\begin{array}{r}0.771 \\
<.0001\end{array}$ & $\begin{array}{r}0.148 \\
<.0001\end{array}$ & $\begin{array}{r}0.071 \\
<.0001\end{array}$ & $\begin{array}{l}-0.068 \\
<.0001\end{array}$ & $\begin{array}{l}-0.113 \\
<.0001\end{array}$ & $\begin{array}{r}-0.056 \\
<.0001\end{array}$ & $\begin{array}{r}-0.142 \\
<.0001\end{array}$ & $\begin{array}{r}0.059 \\
<.0001\end{array}$ & $\begin{array}{r}-0.203 \\
<.0001\end{array}$ & $\begin{array}{r}0.075 \\
<.0001\end{array}$ \\
\hline ROA & & & 1 & $\begin{array}{r}0.169 \\
<.0001\end{array}$ & $\begin{array}{r}0.074 \\
<.0001\end{array}$ & $\begin{array}{r}-0.069 \\
<.0001\end{array}$ & $\begin{array}{l}-0.155 \\
<.0001\end{array}$ & $\begin{array}{r}-0.100 \\
<.0001\end{array}$ & $\begin{array}{r}-0.170 \\
<.0001\end{array}$ & $\begin{array}{r}0.137 \\
<.0001\end{array}$ & $\begin{array}{r}-0.403 \\
<.0001\end{array}$ & $\begin{array}{r}0.169 \\
<.0001\end{array}$ \\
\hline GASET & & & & 1 & $\begin{array}{r}0.384 \\
<.0001\end{array}$ & $\begin{array}{r}-0.097 \\
<.0001\end{array}$ & $\begin{array}{l}-0.076 \\
<.0001\end{array}$ & $\begin{array}{r}0.028 \\
<.0001\end{array}$ & $\begin{array}{r}0.079 \\
<.0001\end{array}$ & $\begin{array}{l}0.010 \\
0.174 \\
\end{array}$ & $\begin{array}{r}0.050 \\
<.0001\end{array}$ & $\begin{array}{l}0.010 \\
0.142\end{array}$ \\
\hline GSALES & & & & & 1 & $\begin{array}{r}-0.073 \\
<.0001\end{array}$ & $\begin{array}{r}-0.049 \\
<.0001\end{array}$ & $\begin{array}{l}0.012 \\
0.100\end{array}$ & $\begin{array}{r}0.036 \\
<.0001\end{array}$ & $\begin{array}{r}-0.021 \\
0.003\end{array}$ & $\begin{array}{r}0.063 \\
<.0001\end{array}$ & $\begin{array}{r}-0.003 \\
0.706\end{array}$ \\
\hline TASET & & & & & & 1 & $\begin{array}{r}0.420 \\
<.0001\end{array}$ & $\begin{array}{r}0.041 \\
<.0001\end{array}$ & $\begin{array}{r}-0.207 \\
<.0001\end{array}$ & $\begin{array}{r}-0.061 \\
<.0001\end{array}$ & $\begin{array}{r}-0.108 \\
<.0001\end{array}$ & $\begin{array}{r}0.051 \\
<.0001\end{array}$ \\
\hline LA & & & & & & & 1 & $\begin{array}{r}-0.044 \\
<.0001\end{array}$ & $\begin{array}{r}-0.134 \\
<.0001\end{array}$ & $\begin{array}{c}-0.191 \\
<.0001\end{array}$ & $\begin{array}{r}0.136 \\
<.0001\end{array}$ & $\begin{array}{r}-0.067 \\
<.0001\end{array}$ \\
\hline $\mathrm{AD}$ & & & & & & & & 1 & $\begin{array}{r}0.158 \\
<.0001\end{array}$ & $\begin{array}{r}0.049 \\
<.0001\end{array}$ & $\begin{array}{l}0.008 \\
0.275\end{array}$ & $\begin{array}{r}0.037 \\
<.0001\end{array}$ \\
\hline $\mathrm{RD}$ & & & & & & & & & 1 & $\begin{array}{r}0.171 \\
<.0001\end{array}$ & $\begin{array}{r}-0.069 \\
<.0001\end{array}$ & $\begin{array}{r}-0.011 \\
0.106\end{array}$ \\
\hline LQ & & & & & & & & & & 1 & $\begin{array}{r}-0.428 \\
<.0001\end{array}$ & $\begin{array}{r}0.144 \\
<.0001\end{array}$ \\
\hline BS & & & & & & & & & & & 1 & $\begin{array}{r}-0.203 \\
<.0001\end{array}$ \\
\hline
\end{tabular}

\subsection{Regression Results}

\subsubsection{Factors that Affect Productivity}

In order to determine where to invest to improve business performance according to the size and business cycle of SMEs, a regression analysis was performed including factors that affect business performance and control variables. We group small and medium companies for each dependent variable and test for differences. In addition, we formulate a method to enhance business performance. The results using the equipment investment ratio (INVEST) as the dependent variable are as follows. In order to identify factors that affect the equipment investment ratio (INVEST), SMEs were grouped according to certain criteria. Firms are grouped in terms of the amount of capital in Panel A, by the number of employees in Panel B, and by the number of years in operation in Panel A of Table 13. According to Table 6, in which data for all SMEs is analyzed, unlike large companies, investment in R\&D has a negative effect on productivity. Grouped data was used to identify factors affecting business growth. When firms are grouped in terms 
of the amount of capital, the results do not differ; when they are grouped in terms of the number of employees, a more significant negative relationship is observed for companies belonging to the top $25 \%$ with respect to R\&D costs and equipment investment productivity. When firms are grouped in terms of the number of years in operation, larger group-wise differences are evident.

For advertising expenses, the results were similar for SMEs with more years in operation and large companies; also, no significant relationship was observed with respect to productivity. For new companies with less than 8 years in operation, investment in advertising had a negative relationship with productivity. For R\&D investment, there was a negative relationship with respect to productivity for companies with 8-20 years in operation.

Table 13. Factors affecting productivity (INVEST)

Panel A. Grouping firms in terms of capital

\begin{tabular}{|c|c|c|c|c|c|c|c|c|}
\hline \multirow{2}{*}{$\begin{array}{l}\text { INVEST } \\
\text { Variable }\end{array}$} & \multicolumn{2}{|c|}{$1 Q$} & \multicolumn{2}{|c|}{$2 Q$} & \multicolumn{2}{|c|}{ 3Q } & \multicolumn{2}{|c|}{$4 Q$} \\
\hline & Estimate & t-value & Estimate & t-value & Estimate & t-value & Estimate & t-value \\
\hline Intercept & 0.0535 & $2.97^{* * *}$ & 0.0617 & 1.34 & -0.0369 & -1.04 & 0.0197 & $1.80^{*}$ \\
\hline TASET & 0.0066 & $8.88^{* * *}$ & 0.0072 & $3.62^{* * *}$ & 0.0099 & $6.21^{* * *}$ & 0.0033 & $6.85^{* * *}$ \\
\hline$L A$ & -0.0114 & $-31.48^{* * *}$ & -0.0132 & $-33.95^{* * *}$ & -0.0103 & $-30.39^{* * *}$ & -0.0050 & $-23.54^{* * *}$ \\
\hline$A D$ & -0.0207 & -0.66 & -0.0420 & -1.14 & -0.0540 & -1.56 & -0.0043 & -0.25 \\
\hline$R D$ & -0.0484 & $-3.83^{* * *}$ & -0.0387 & $-2.97^{* * *}$ & 0.0054 & 0.52 & -0.0185 & $-3.77^{* * *}$ \\
\hline$L Q$ & -0.0001 & -0.67 & -0.0002 & -1.20 & -0.0004 & $-2.38^{* *}$ & -0.0001 & -0.98 \\
\hline$B S$ & 0.0012 & 0.37 & -0.0003 & -0.06 & -0.0109 & $-2.36^{* *}$ & 0.0015 & 1.17 \\
\hline$I N R T$ & 0.0000 & -0.80 & 0.0000 & 0.59 & 0.0000 & -0.74 & 0.0000 & 1.57 \\
\hline \# of firms & \multicolumn{2}{|c|}{5,031} & \multicolumn{2}{|c|}{5,031} & \multicolumn{2}{|c|}{5,031} & \multicolumn{2}{|c|}{5,031} \\
\hline Adjusted $\mathrm{R}^{2}$ & \multicolumn{2}{|c|}{0.2128} & \multicolumn{2}{|c|}{0.253} & \multicolumn{2}{|c|}{0.2351} & \multicolumn{2}{|c|}{0.1718} \\
\hline
\end{tabular}

Panel B. Grouping firms in terms of number of employees

\begin{tabular}{|c|c|c|c|c|c|c|c|c|}
\hline \multirow{2}{*}{$\begin{array}{l}\text { INVEST } \\
\text { Variable }\end{array}$} & \multicolumn{2}{|c|}{ 1Q } & \multicolumn{2}{|c|}{$2 Q$} & \multicolumn{2}{|c|}{ 3Q } & \multicolumn{2}{|c|}{$4 Q$} \\
\hline & Estimate & t-value & Estimate & t-value & Estimate & t-value & Estimate & t-value \\
\hline Intercept & -0.0035 & -0.91 & -0.0452 & -4.12 & -0.0466 & $-3.86^{* * *}$ & -0.0683 & $-3.1^{* * *}$ \\
\hline TASET & 0.0042 & $23.16^{* * *}$ & 0.0101 & $21.89^{* * *}$ & 0.0114 & $22.45^{* * *}$ & 0.0165 & $18.24^{* * *}$ \\
\hline$L A$ & -0.0054 & $-39.02^{* * *}$ & -0.0107 & $-34.14^{* * *}$ & -0.0121 & $-40.16^{* * *}$ & -0.0166 & $-37.62^{* * *}$ \\
\hline$A D$ & -0.0140 & -1.7 & -0.0146 & -0.65 & -0.0723 & $-2.81^{* * *}$ & 0.0016 & 0.03 \\
\hline$R D$ & -0.0190 & $-5.66^{* * *}$ & -0.0229 & $-3.01^{*}$ & -0.0293 & $-3.8^{* *}$ & -0.0138 & -1.07 \\
\hline$L Q$ & -0.0002 & $-2.61^{* * *}$ & 0.0000 & -0.07 & -0.0002 & $-1.67^{*}$ & -0.0007 & $-4.56^{* * *}$ \\
\hline$B S$ & -0.0001 & -0.12 & 0.0029 & 1.92 & 0.0032 & 2.08 & 0.0030 & 1.09 \\
\hline$I N R T$ & 0.0000 & 0.67 & 0.0000 & 0.29 & 0.0000 & 5.49 & 0.0000 & 0.05 \\
\hline \# of firms & \multicolumn{2}{|c|}{5,107} & \multicolumn{2}{|c|}{5,050} & \multicolumn{2}{|c|}{5,092} & \multicolumn{2}{|c|}{4,875} \\
\hline Adjusted $\mathrm{R}^{2}$ & \multicolumn{2}{|c|}{0.2745} & \multicolumn{2}{|c|}{0.2600} & \multicolumn{2}{|c|}{0.3012} & \multicolumn{2}{|c|}{0.2847} \\
\hline
\end{tabular}

Panel C. Grouping firms in terms of years in operation

\begin{tabular}{|c|c|c|c|c|c|c|c|c|}
\hline \multirow{2}{*}{$\begin{array}{l}\text { INVEST } \\
\text { Variable }\end{array}$} & \multicolumn{2}{|c|}{$1 Q$} & \multicolumn{2}{|c|}{ 2Q } & \multicolumn{2}{|c|}{ 3Q } & \multicolumn{2}{|c|}{$4 Q$} \\
\hline & Estimate & t-value & Estimate & t-value & Estimate & t-value & Estimate & t-value \\
\hline Intercept & 0.0655 & $5.10^{* * *}$ & 0.0783 & $5.28^{* * *}$ & 0.0386 & $2.74^{* * *}$ & -0.0004 & -0.03 \\
\hline TASET & 0.0058 & $12.16^{* * *}$ & 0.0055 & $9.51^{* * *}$ & 0.0062 & $11.84^{* * *}$ & 0.0060 & $11.3^{* * *} 7$ \\
\hline$L A$ & -0.0103 & $-31.04^{* * *}$ & -0.0114 & $-32.87^{* * *}$ & -0.0102 & $-31.49^{* * *}$ & -0.0076 & $-23.21^{* * *}$ \\
\hline$A D$ & -0.0458 & -1.39 & 0.0304 & 0.85 & -0.0172 & -0.56 & -0.0431 & $-1.74^{*}$ \\
\hline$R D$ & -0.0074 & -0.43 & -0.0401 & $-2.89^{* * *}$ & -0.0267 & $-3.16^{* * *}$ & -0.0101 & -1.35 \\
\hline$L Q$ & 0.0000 & 0.06 & -0.0001 & -0.48 & -0.0003 & $-2.24^{* *}$ & -0.0004 & $-2.23^{* *}$ \\
\hline$B \bar{S}$ & 0.0032 & $1.74^{*}$ & 0.0022 & 1.06 & 0.0016 & 0.86 & 0.0008 & 0.37 \\
\hline$I N R T$ & 0.0000 & -0.83 & 0.0000 & 1.37 & 0.0000 & 0.28 & 0.0000 & 0.84 \\
\hline \# of firms & \multicolumn{2}{|c|}{5,215} & \multicolumn{2}{|c|}{4,917} & \multicolumn{2}{|c|}{6,044} & \multicolumn{2}{|c|}{3,948} \\
\hline Adjusted $\mathrm{R}^{2}$ & \multicolumn{2}{|c|}{0.1992} & \multicolumn{2}{|c|}{0.2507} & \multicolumn{2}{|c|}{0.1975} & \multicolumn{2}{|c|}{0.2274} \\
\hline
\end{tabular}


The results of the analysis of factors affecting labor productivity $(\angle B P R O)$ are presented in Panels $\mathrm{A} \sim \mathrm{C}$ of Table 14 , which shows that investment advertising has a positive effect on labor productivity. However, when firms are grouped, for larger SMEs (in terms of amount of capital and number of employees) and those with many years in operation, although investment in advertising increases productivity, the result did not hold for other cases. This could be interpreted as follows: investment in advertising increases the effects of economies of scale and market entry. However, R\&D expenditure had a negative effect on labor productivity, which was the case for all SMEs.

Table 14. Factors affecting productivity $(L B P R O)$

Panel A. Grouping firms in terms of capital

\begin{tabular}{|c|c|c|c|c|c|c|c|c|}
\hline \multirow{2}{*}{$\begin{array}{c}\text { LBPRO } \\
\text { Variable }\end{array}$} & \multicolumn{2}{|c|}{$1 Q$} & \multicolumn{2}{|c|}{$2 Q$} & \multicolumn{2}{|c|}{$3 Q$} & \multicolumn{2}{|c|}{$4 Q$} \\
\hline & Estimate & t-value & Estimate & t-value & Estimate & t-value & Estimate & t-value \\
\hline Intercept & -398.3367 & $-21.25^{* * *}$ & -31.9781 & -1.58 & -87.5873 & $-6.46^{* * *}$ & -71.8819 & $-9.25^{* * *}$ \\
\hline TASET & 10.5471 & $13.7^{* * *}$ & -0.3589 & -0.42 & 2.4892 & $4.11^{* * *}$ & 2.3452 & $6.88^{* * *}$ \\
\hline$L A$ & 7.8125 & $20.83^{* * *}$ & 2.6602 & $15.71^{* * *}$ & 2.1752 & $16.78^{* * *}$ & 1.1668 & $7.72^{* * *}$ \\
\hline$A D$ & 60.0941 & $1.83^{*}$ & -19.8044 & -1.23 & 2.9037 & 0.22 & 7.2921 & 0.58 \\
\hline$R D$ & -43.7500 & $-3.32^{* * *}$ & -34.7034 & $-6.09^{* * *}$ & -19.7021 & $-5.00^{* * *}$ & -14.6323 & $-4.18^{* * *}$ \\
\hline$L Q$ & -0.2436 & -1.58 & 0.0935 & 1.1 & 0.0140 & 0.25 & 0.0457 & 0.59 \\
\hline$B \tilde{S}$ & -16.0963 & $-5.00^{* * *}$ & -0.7607 & -0.33 & -6.7647 & $-3.84^{* * *}$ & -4.9340 & $-5.51^{* * *}$ \\
\hline$I N R T$ & 0.0042 & $5.42^{* * *}$ & 0.0016 & $3.59^{* * *}$ & 0.0010 & $1.72^{*}$ & 0.0016 & 1.36 \\
\hline \# of firms & \multicolumn{2}{|c|}{5,031} & \multicolumn{2}{|c|}{5,031} & \multicolumn{2}{|c|}{5,031} & \multicolumn{2}{|c|}{5,031} \\
\hline Adjusted $\mathrm{R}^{2}$ & \multicolumn{2}{|c|}{0.3561} & \multicolumn{2}{|c|}{0.0734} & \multicolumn{2}{|c|}{0.1488} & \multicolumn{2}{|c|}{0.1393} \\
\hline
\end{tabular}

Panel B. Grouping firms in terms of number of employees

\begin{tabular}{|c|c|c|c|c|c|c|c|c|}
\hline \multirow{2}{*}{$\begin{array}{c}\text { LBPRO } \\
\text { Variable }\end{array}$} & \multicolumn{2}{|c|}{ 1Q } & \multicolumn{2}{|c|}{$2 Q$} & \multicolumn{2}{|c|}{ 3Q } & \multicolumn{2}{|c|}{$4 Q$} \\
\hline & Estimate & t-value & Estimate & t-value & Estimate & t-value & Estimate & t-value \\
\hline Intercept & -102.4719 & $-23.64^{* * *}$ & -149.1133 & $-25.73^{* * *}$ & -165.1917 & $-23.65^{* * *}$ & -470.6211 & $-27.96^{* * *}$ \\
\hline TASET & 4.3450 & $21.21^{* * *}$ & 6.8148 & $27.91^{* * *}$ & 7.1564 & $24.23^{* * *}$ & 16.5772 & $23.98^{* * *}$ \\
\hline$L A$ & 0.3330 & $2.13^{* *}$ & -0.5635 & $-3.41^{* * *}$ & -0.1366 & -0.78 & 3.8833 & $11.5^{* * *}$ \\
\hline$A D$ & 39.8648 & $4.26^{* * *}$ & 51.1140 & $4.3^{* * *}$ & -23.2587 & -1.56 & -28.9712 & -0.81 \\
\hline$R D$ & -1.2043 & -0.32 & 2.9678 & 0.74 & -24.9859 & $-5.59^{* * *}$ & -50.9333 & $-5.2^{* * *}$ \\
\hline$L Q$ & -0.0660 & -0.96 & -0.0057 & -0.06 & -0.3292 & $-4.19^{* * *}$ & -0.1206 & -1.02 \\
\hline$B S$ & -2.0571 & $-2.93^{* * *}$ & -0.9790 & -1.23 & -4.8598 & $-5.48^{* * *}$ & -7.4901 & $-3.53^{* * *}$ \\
\hline$I N R T$ & 0.0009 & $3.6^{* * *}$ & 0.0010 & $2.47^{* *}$ & 0.0015 & $3.05^{* * *}$ & 0.0086 & $6.23^{* * *}$ \\
\hline \# of firms & \multicolumn{2}{|c|}{5,107} & \multicolumn{2}{|c|}{5,050} & \multicolumn{2}{|c|}{5,092} & \multicolumn{2}{|c|}{4,875} \\
\hline Adjusted $\mathrm{R}^{2}$ & \multicolumn{2}{|c|}{0.1959} & \multicolumn{2}{|c|}{0.2857} & \multicolumn{2}{|c|}{0.2707} & \multicolumn{2}{|c|}{0.3290} \\
\hline
\end{tabular}

Panel C. Grouping firms in terms of years in operation

\begin{tabular}{|c|c|c|c|c|c|c|c|c|}
\hline \multirow{2}{*}{$\begin{array}{c}\text { LBPRO } \\
\text { Variable }\end{array}$} & \multicolumn{2}{|c|}{ 1Q } & \multicolumn{2}{|c|}{ 2Q } & \multicolumn{2}{|c|}{ 3Q } & \multicolumn{2}{|c|}{$4 Q$} \\
\hline & Estimate & t-value & Estimate & t-value & Estimate & t-value & Estimate & t-value \\
\hline Intercept & -287.2999 & $-23.35^{* * *}$ & -169.7555 & $-17.44^{* * *}$ & -100.2075 & $-12.56^{* * *}$ & -87.7729 & $-9.03^{* * *}$ \\
\hline TASET & 6.3704 & $14.05^{* * *}$ & 4.1566 & $10.92^{* * *}$ & 2.1377 & $7.25^{* * *}$ & 2.0051 & $5.09^{* * *}$ \\
\hline$L A$ & 6.1685 & $19.36^{* * *}$ & 4.0158 & $17.61^{* * *}$ & 3.4749 & $18.98^{* * *}$ & 2.8445 & $11.67^{* * *}$ \\
\hline$A D$ & 149.7093 & $4.76^{* * *}$ & 19.4446 & 0.83 & -17.2368 & -0.99 & -25.5033 & -1.37 \\
\hline$R D$ & -70.0964 & $-4.31^{* * *}$ & -31.1901 & $-3.43^{* * *}$ & -24.1011 & $-5.04^{* * *}$ & -23.2347 & $-4.14^{* * *}$ \\
\hline$L Q$ & 0.2022 & 1.17 & -0.0504 & -0.62 & -0.0979 & -1.14 & 0.0092 & 0.07 \\
\hline$B S$ & 1.2604 & 0.71 & -3.4801 & $-2.59^{* * *}$ & -8.4361 & $-7.81^{* * *}$ & -5.2926 & $-3.47^{* * *}$ \\
\hline INRT & 0.0030 & $4.24^{* * *}$ & 0.0046 & $7.07^{* * *}$ & 0.0008 & 1.4 & 0.0015 & 1.48 \\
\hline \# of firms & \multicolumn{2}{|c|}{5,215} & \multicolumn{2}{|c|}{4,917} & \multicolumn{2}{|c|}{6,044} & \multicolumn{2}{|c|}{3,948} \\
\hline Adjusted $\mathrm{R}^{2}$ & \multicolumn{2}{|c|}{0.3332} & \multicolumn{2}{|c|}{0.1965} & \multicolumn{2}{|c|}{0.1225} & \multicolumn{2}{|c|}{0.1480} \\
\hline
\end{tabular}

\subsubsection{Factors Affecting Profitability}

The analysis of $R O E$ shows the biggest difference in business performance between large and small/medium companies (Table 15). As shown in Table 8, the values for firm size (TASET) and profitability show positive 
relationships and economies of scale. However, for SMEs, profitability declined as size increased. In the analysis of firms grouped in different ways, for firms with the largest amounts of capital, no relationship was evident between $R O E$ and firm size. This finding implies that, for SMEs, the larger the company, the lower the profitability. In terms of $R O E$, economies of scale are effective for large companies. Otherwise, for SMEs an increase in size leads to a decline in profit due to lack of effectiveness. Also, investment in intangible assets such as advertising and R\&D has a negative effect on $R O E$ in the short term for SMEs. In addition, the significance of this difference increases for small and new companies.

Table 15. Factors affecting profitability $(R O E)$

Panel A. Grouping firms in terms of capital

\begin{tabular}{|c|c|c|c|c|c|c|c|c|}
\hline \multirow{2}{*}{$\begin{array}{c}\text { ROE } \\
\text { Variable }\end{array}$} & \multicolumn{2}{|c|}{$1 Q$} & \multicolumn{2}{|c|}{$2 Q$} & \multicolumn{2}{|c|}{ 3Q } & \multicolumn{2}{|c|}{ 4Q } \\
\hline & Estimate & t-value & Estimate & t-value & Estimate & t-value & Estimate & t-value \\
\hline Intercept & 0.5450 & $4.26^{* * *}$ & 3.8107 & $10.26^{* * *}$ & 4.3390 & $11.11^{* * *}$ & 4.7877 & $10.22^{* * *}$ \\
\hline TASET & 0.0016 & 0.3 & -0.1472 & $-9.27^{* * *}$ & -0.1662 & $-9.53^{* * *}$ & -0.1476 & $-7.07^{* * *}$ \\
\hline$L A$ & -0.0233 & $-9.11^{* * *}$ & -0.0234 & $-7.52^{* * *}$ & -0.0188 & $-5.03^{* * *}$ & -0.0085 & -1.03 \\
\hline$A D$ & -0.5623 & $-2.51^{* *}$ & -0.5363 & $-1.81^{*}$ & -0.9725 & $-2.56^{* *}$ & -2.9670 & $-3.75^{* * *}$ \\
\hline$R D$ & -1.0749 & $-11.95^{* * *}$ & -1.1896 & $-11.35^{* * *}$ & -1.3650 & $-12.03^{* * *}$ & -3.2089 & $-16.54^{* * *}$ \\
\hline$L Q$ & -0.0011 & -1.06 & -0.0018 & -1.17 & 0.0007 & 0.42 & -0.0087 & $-2.23^{* *}$ \\
\hline$B S$ & -0.1575 & $-7.16^{* * *}$ & -0.0132 & -0.31 & -0.0273 & -0.54 & -1.3440 & $-15.74^{* * *}$ \\
\hline$I N R T$ & 0.0000 & $6.70^{* * *}$ & 0.0000 & $4.80^{* * *}$ & 0.0001 & $4.05^{* * *}$ & 0.0002 & $3.40^{* * *}$ \\
\hline \# of firms & \multicolumn{2}{|c|}{5,031} & \multicolumn{2}{|c|}{5,031} & \multicolumn{2}{|c|}{5,031} & \multicolumn{2}{|c|}{4,419} \\
\hline Adjusted $\mathrm{R}^{2}$ & \multicolumn{2}{|c|}{0.075} & \multicolumn{2}{|c|}{0.0981} & \multicolumn{2}{|c|}{0.0977} & \multicolumn{2}{|c|}{0.168} \\
\hline
\end{tabular}

Panel B. Grouping firms in terms of number of employees

\begin{tabular}{|c|c|c|c|c|c|c|c|c|}
\hline \multirow{2}{*}{$\begin{array}{c}\text { ROE } \\
\text { Variable }\end{array}$} & \multicolumn{2}{|c|}{ 1Q } & \multicolumn{2}{|c|}{$2 Q$} & \multicolumn{2}{|c|}{$3 Q$} & \multicolumn{2}{|c|}{$4 Q$} \\
\hline & Estimate & t-value & Estimate & t-value & Estimate & t-value & Estimate & t-value \\
\hline Intercept & 1.6316 & $10.36^{* * *}$ & 2.4262 & $10.8^{* * *}$ & 2.2502 & $10.03^{* * *}$ & 2.4350 & $10.82^{* * *}$ \\
\hline TASET & -0.0417 & $-5.6^{* * *}$ & -0.0534 & $-5.71^{* * *}$ & -0.0674 & $-7.51^{* * *}$ & -0.0783 & $-8.66^{* * *}$ \\
\hline$L A$ & -0.0172 & $-3.01^{* * *}$ & -0.0306 & $-4.8^{* * *}$ & -0.0162 & $-3.04^{* * *}$ & -0.0124 & $-2.81^{* * *}$ \\
\hline$A D$ & 0.1139 & 0.33 & -1.4410 & $-3.04^{* * *}$ & -1.0998 & $-2.16^{* *}$ & -2.2115 & $-4.51^{* * *}$ \\
\hline$R D$ & -1.4082 & $-9.73^{* * *}$ & -2.4311 & $-15.3^{* * *}$ & -1.7390 & $-12.3^{* * *}$ & -1.8852 & $-14.43^{* * *}$ \\
\hline$L Q$ & -0.0039 & -1.54 & -0.0105 & $-2.68^{* * *}$ & -0.0049 & $-2.05^{* *}$ & -0.0039 & $-2.52^{* *}$ \\
\hline$B S$ & -0.3714 & $-12.76^{* * *}$ & -0.7259 & $-18.9^{* * *}$ & -0.4901 & $-14.97^{* * *}$ & -0.4640 & $-13.48^{* * *}$ \\
\hline INRT & 0.0000 & $1.72^{*}$ & 0.0000 & 1.62 & 0.0000 & $2.24^{* *}$ & 0.0000 & $2.31^{* *}$ \\
\hline \# of firms & \multicolumn{2}{|c|}{5,011} & \multicolumn{2}{|c|}{4,899} & \multicolumn{2}{|c|}{4,951} & \multicolumn{2}{|c|}{4,651} \\
\hline Adjusted $\mathrm{R}^{2}$ & \multicolumn{2}{|c|}{0.0709} & \multicolumn{2}{|c|}{0.1306} & \multicolumn{2}{|c|}{0.0875} & \multicolumn{2}{|c|}{0.112} \\
\hline
\end{tabular}

Panel C. Grouping firms in terms of years in operation

\begin{tabular}{|c|c|c|c|c|c|c|c|c|}
\hline \multirow{2}{*}{$\begin{array}{c}\text { ROE } \\
\text { Variable }\end{array}$} & \multicolumn{2}{|c|}{$1 Q$} & \multicolumn{2}{|c|}{$2 Q$} & \multicolumn{2}{|c|}{ 3Q } & \multicolumn{2}{|c|}{$4 Q$} \\
\hline & Estimate & t-value & Estimate & t-value & Estimate & t-value & Estimate & t-value \\
\hline Intercept & 1.0448 & $6.24^{* * *}$ & 1.0632 & $5.75^{* * *}$ & 2.2733 & $11.87^{* * *}$ & 2.1693 & $9.01^{* * *}$ \\
\hline TASET & -0.0116 & $-1.92^{*}$ & -0.0220 & $-3.05^{* * *}$ & -0.0503 & $-7.15^{* * *}$ & -0.0613 & $-6.46^{* * *}$ \\
\hline$L A$ & -0.0203 & $-4.75^{* * *}$ & -0.0196 & $-4.51^{* * *}$ & -0.0263 & $-5.97^{* * *}$ & -0.0146 & $-2.46^{* *}$ \\
\hline$A D$ & -0.9280 & $-2.2^{* *}$ & -0.8851 & $-1.93^{*}$ & -1.4184 & $-3.2^{* * *}$ & -1.3185 & $-2.79^{* * *}$ \\
\hline$R D$ & -1.1926 & $-5.53^{* * *}$ & -2.0739 & $-11.7^{* * *}$ & -1.6307 & $-13.68^{* * *}$ & -2.6831 & $-19.24^{* * *}$ \\
\hline$L Q$ & -0.0116 & $-4.93^{* * *}$ & -0.0060 & $-3.9^{* * *}$ & -0.0041 & $-1.97^{* *}$ & 0.0002 & 0.08 \\
\hline$B S$ & -0.4901 & $-16.75^{* * *}$ & -0.4443 & $-14.74^{* * *}$ & -0.5809 & $-18.15^{* * *}$ & -0.6757 & $-14.95^{* * *}$ \\
\hline INRT & 0.0000 & $2.50^{* *}$ & 0.0000 & 1.11 & 0.0000 & 1.32 & 0.0001 & $3.10^{* * *}$ \\
\hline \# of firms & \multicolumn{2}{|c|}{5,096} & \multicolumn{2}{|c|}{4,806} & \multicolumn{2}{|c|}{5,859} & \multicolumn{2}{|c|}{3,751} \\
\hline Adjusted $\mathrm{R}^{2}$ & \multicolumn{2}{|c|}{0.0795} & \multicolumn{2}{|c|}{0.079} & \multicolumn{2}{|c|}{0.1005} & \multicolumn{2}{|c|}{0.1610} \\
\hline
\end{tabular}

The results are similar in terms of $R O A$ presented in panels $\mathrm{A} \sim \mathrm{C}$ of Table 16 . When firms are grouped in terms of the amount of capital, for smaller SMEs, size and profitability are in a negative relationship. Using other criteria, the same negative relationship between these two variables is observed. When firms are grouped in terms of number of 
employees, even for companies with only a few employees, investment in advertising adversely affected profitability. On the other hand, for companies with many employees, no relationship was evident, similar to the case of large companies. R\&D expenditure showed a negative relationship for SMEs. Unlike large companies, R\&D requiring longterm investment adversely affected profitability.

Table 16. Factors affecting profitability $(R O A)$

Panel A. Grouping firms in terms of capital

\begin{tabular}{|c|c|c|c|c|c|c|c|c|}
\hline ROA & \multicolumn{2}{|c|}{$1 Q$} & \multicolumn{2}{|c|}{$2 Q$} & \multicolumn{2}{|c|}{ 3Q } & \multicolumn{2}{|c|}{$4 Q$} \\
\hline Variable & Estimate & t-value & Estimate & t-value & Estimate & t-value & Estimate & t-value \\
\hline Intercept & 0.2510 & $4.47^{* * *}$ & 0.9483 & $7.33^{* * *}$ & 0.8420 & $7.42^{* * *}$ & 0.8152 & $11.72^{* * *}$ \\
\hline TASET & 0.0012 & 0.54 & -0.0337 & $-6.09^{* * *}$ & -0.0245 & $-4.83^{* * *}$ & -0.0156 & $-5.11^{* * *}$ \\
\hline$L A$ & -0.0096 & $-8.54^{* * *}$ & -0.0086 & $-7.96^{* * *}$ & -0.0070 & $-6.48^{* * *}$ & -0.0047 & $-3.5^{* * *}$ \\
\hline$A D$ & -0.3207 & $-3.27^{* * *}$ & -0.2575 & $-2.5^{* *}$ & -0.5200 & $-4.71^{* * *}$ & -0.6717 & $-5.98^{* * *}$ \\
\hline$R D$ & -0.5568 & $-14.12^{* * *}$ & -0.4879 & $-13.37^{* * *}$ & -0.4701 & $-14.25^{* * *}$ & -0.6762 & $-21.57^{* * *}$ \\
\hline$L Q$ & -0.0001 & -0.2 & -0.0002 & -0.32 & 0.0006 & 1.23 & -0.0016 & $-2.29^{* *}$ \\
\hline$\overline{B S}$ & -0.1038 & $-10.76^{* * *}$ & -0.1018 & $-6.89^{* * *}$ & -0.1663 & $-11.25^{* * *}$ & -0.3048 & $-38.05^{* * *}$ \\
\hline$I N R T$ & 0.0000 & $12.02^{* * *}$ & 0.0000 & $10.14^{* * *}$ & 0.0000 & $6.89^{* * *}$ & 0.0001 & $6.82^{* * *}$ \\
\hline \# of firms & \multicolumn{2}{|c|}{5,031} & \multicolumn{2}{|c|}{5,031} & \multicolumn{2}{|c|}{5,031} & \multicolumn{2}{|c|}{5,031} \\
\hline Adjusted $\mathrm{R}^{2}$ & \multicolumn{2}{|c|}{0.1272} & \multicolumn{2}{|c|}{0.171} & \multicolumn{2}{|c|}{0.2073} & \multicolumn{2}{|c|}{0.3762} \\
\hline
\end{tabular}

Panel B. Grouping firms in terms of number of employees

\begin{tabular}{|c|c|c|c|c|c|c|c|c|}
\hline \multirow{2}{*}{$\begin{array}{c}\text { ROA } \\
\text { Variable }\end{array}$} & \multicolumn{2}{|c|}{$1 Q$} & \multicolumn{2}{|c|}{$2 Q$} & \multicolumn{2}{|c|}{ 3Q } & \multicolumn{2}{|c|}{$4 Q$} \\
\hline & Estimate & t-value & Estimate & t-value & Estimate & t-value & Estimate & t-value \\
\hline Intercept & 0.6730 & $15.57^{* * *}$ & 0.8245 & $15.72^{* * *}$ & 1.0057 & $19^{* * *}$ & 0.7681 & $13.81^{* * *}$ \\
\hline TASET & -0.0147 & $-7.22^{* * *}$ & -0.0187 & $-8.48^{* * *}$ & -0.0285 & $-12.74^{* * *}$ & -0.0243 & $-10.64^{* * *}$ \\
\hline$L A$ & -0.0068 & $-4.36^{* * *}$ & -0.0097 & $-6.46^{* * *}$ & -0.0052 & $-3.91^{* * *}$ & -0.0030 & $-2.68^{* * *}$ \\
\hline$A D$ & -0.1287 & -1.38 & -0.7219 & $-6.71^{* * *}$ & -0.6189 & $-5.49^{* * *}$ & -0.6562 & $-5.57^{* * *}$ \\
\hline$R D$ & -0.4216 & $-11.07^{* * *}$ & -0.6915 & $-19^{* * *}$ & -0.6521 & $-19.25^{* * *}$ & -0.6049 & $-18.68^{* * *}$ \\
\hline$L Q$ & -0.0008 & -1.21 & -0.0006 & -0.65 & -0.0015 & $-2.49^{* *}$ & -0.0011 & $-2.76^{* * *}$ \\
\hline$B S$ & -0.2031 & $-29.05^{* * *}$ & -0.2268 & $-31.59^{* * *}$ & -0.2123 & $-31.62^{* * *}$ & -0.1835 & $-26.18^{* * *}$ \\
\hline$I N R T$ & 0.0000 & $5.89^{* * *}$ & 0.0000 & $6.85^{* * *}$ & 0.0000 & 7.56 & 0.0000 & $7.58^{* * *}$ \\
\hline \# of firms & \multicolumn{2}{|c|}{5,107} & \multicolumn{2}{|c|}{5,050} & \multicolumn{2}{|c|}{5,092} & \multicolumn{2}{|c|}{4,875} \\
\hline Adjusted $\mathrm{R}^{2}$ & \multicolumn{2}{|c|}{0.2218} & \multicolumn{2}{|c|}{0.2857} & \multicolumn{2}{|c|}{0.2753} & \multicolumn{2}{|c|}{0.249} \\
\hline
\end{tabular}

Panel C. Grouping firms in terms of years in operation

\begin{tabular}{|c|c|c|c|c|c|c|c|c|}
\hline \multirow{2}{*}{$\begin{array}{c}\text { ROA } \\
\text { Variable }\end{array}$} & \multicolumn{2}{|c|}{ 1Q } & \multicolumn{2}{|c|}{$2 Q$} & \multicolumn{2}{|c|}{ 3Q } & \multicolumn{2}{|c|}{$4 Q$} \\
\hline & Estimate & t-value & Estimate & t-value & Estimate & t-value & Estimate & t-value \\
\hline Intercept & 0.4188 & $9.34^{* * *}$ & 0.5780 & $12.24^{* * *}$ & 0.8311 & $17.28^{* * *}$ & 0.6973 & $13.26^{* * *}$ \\
\hline TASET & -0.0048 & $-2.89^{* * *}$ & -0.0136 & $-7.37^{* * *}$ & -0.0182 & $-10.22^{* * *}$ & -0.0168 & $-7.87^{* * *}$ \\
\hline$L A$ & -0.0077 & $-6.61^{* * * *}$ & -0.0062 & $-5.64^{* * * *}$ & -0.0080 & $-7.26^{* * *}$ & -0.0046 & $-3.48^{* * * *}$ \\
\hline$A D$ & -0.3200 & $-2.79^{* * *}$ & -0.5159 & $-4.55^{* * *}$ & -0.5477 & $-5.24^{* * *}$ & -0.5834 & $-5.81^{* * *}$ \\
\hline$R D$ & -0.5419 & $-9.14^{* * *}$ & -0.6850 & $-15.52^{* * *}$ & -0.5853 & $-20.28^{* * *}$ & -0.7360 & $-24.28^{* * *}$ \\
\hline$L Q$ & -0.0031 & $-4.92^{* * *}$ & -0.0020 & $-5.07^{* * *}$ & -0.0003 & -0.56 & -0.0006 & -0.85 \\
\hline$B S$ & -0.1715 & $-26.56^{* * *}$ & -0.1872 & $-28.69^{* * *}$ & -0.2469 & $-37.9^{* * *}$ & -0.2555 & $-30.95^{* * *}$ \\
\hline INRT & 0.0000 & $8.83^{* * *}$ & 0.0000 & $5.99^{* * *}$ & 0.0000 & $6.95^{* * *}$ & 0.0000 & $7.84^{* * *}$ \\
\hline \# of firms & \multicolumn{2}{|c|}{5,215} & \multicolumn{2}{|c|}{4,917} & \multicolumn{2}{|c|}{6,044} & \multicolumn{2}{|c|}{3,948} \\
\hline Adjusted $\mathrm{R}^{2}$ & \multicolumn{2}{|c|}{0.191} & \multicolumn{2}{|c|}{0.2289} & \multicolumn{2}{|c|}{0.2966} & \multicolumn{2}{|c|}{0.3459} \\
\hline
\end{tabular}

\subsubsection{Factors Affecting Growth}

The following results in Table 17 are the results of our analysis using growth as the dependent variable. First, GASET was used to conduct the analysis. As shown in Table 10, growth affected the business performance of both large companies and SMEs. Economies of scale also affected growth. For large companies, large economies of scale were related to high growth, which seems to indicate a concentration of economic power in large companies. However, for 
SMEs, smaller size was related to high growth. In the analysis of firms by group, the amount of capital and the number of employees were highly correlated with growth when SMEs were larger. Otherwise, these variables were related to high growth. Unlike productivity and profitability, investment in intangible assets was effective in terms of asset growth. Unlike large companies, advertising and $R \& D$ expenditure had a positive effect on increasing firm size for SMEs. In particular, for small companies, investment in advertising helped increase assets. This finding implies that, when a firm is smaller than a certain size, advertising increases awareness and has a positive effect on attracting investment. For R\&D, when firms were grouped in terms of firm size, there were no differences in terms of groups or increased assets. However, when the number of years in operation was greater than 20, assets grew. Therefore, we posit that when companies enter a certain stage, R\&D investment can increase asset growth rates.

Table 17. Factors affecting growth (GASET)

Panel A. Grouping firms in terms of capital

\begin{tabular}{|c|c|c|c|c|c|c|c|c|}
\hline GASET & \multicolumn{2}{|c|}{$1 Q$} & \multicolumn{2}{|c|}{$2 Q$} & \multicolumn{2}{|c|}{$3 Q$} & \multicolumn{2}{|c|}{$4 Q$} \\
\hline Variable & Estimate & t-value & Estimate & t-value & Estimate & t-value & Estimate & t-value \\
\hline Intercept & 1.2132 & $5.19^{* * *}$ & 1.0974 & $2.16^{* *}$ & 1.5678 & $2.43^{* *}$ & 4.3639 & $10.6^{* * *}$ \\
\hline TASET & 0.0177 & $1.85^{*}$ & 0.0110 & 0.51 & 0.0127 & 0.44 & -0.1079 & $-5.97^{* * *}$ \\
\hline$L A$ & -0.0212 & $-4.54^{* * *}$ & -0.0113 & $-2.62^{* * *}$ & -0.0296 & $-4.81^{* * *}$ & -0.0127 & -1.6 \\
\hline$A D$ & -0.2622 & -0.64 & -0.4227 & -1.03 & 1.6374 & $2.61^{* * *}$ & 1.5553 & $2.3^{* *}$ \\
\hline$R D$ & 0.5420 & $3.3^{* * *}$ & 0.8021 & $5.55^{* * *}$ & 0.8289 & $4.34^{* * *}$ & 0.5875 & $3.13^{* * *}$ \\
\hline$L Q$ & 0.0042 & $2.17^{* *}$ & 0.0050 & $2.34^{* *}$ & 0.0112 & $4.13^{* * *}$ & -0.0033 & -0.77 \\
\hline$B S$ & 0.1972 & $4.92^{* * *}$ & 0.3202 & $5.51^{* * *}$ & 0.3566 & $4.25^{* * *}$ & -0.1198 & $-2.55^{* *}$ \\
\hline INRT & 0.0000 & 1.54 & 0.0000 & $3.93^{* * *}$ & 0.0001 & $3.75^{* * *}$ & 0.0002 & 2.53 \\
\hline \# of firms & \multicolumn{2}{|c|}{4,998} & \multicolumn{2}{|c|}{4,980} & \multicolumn{2}{|c|}{4,909} & \multicolumn{2}{|c|}{4,806} \\
\hline Adjusted $\mathrm{R}^{2}$ & \multicolumn{2}{|c|}{0.0169} & \multicolumn{2}{|c|}{0.0268} & \multicolumn{2}{|c|}{0.0232} & \multicolumn{2}{|c|}{0.0333} \\
\hline
\end{tabular}

Panel B. Grouping firms in terms of number of employees

\begin{tabular}{|c|c|c|c|c|c|c|c|c|}
\hline \multirow{2}{*}{$\begin{array}{c}\text { GASET } \\
\text { Variable }\end{array}$} & \multicolumn{2}{|c|}{$1 Q$} & \multicolumn{2}{|c|}{$2 Q$} & \multicolumn{2}{|c|}{ 3Q } & \multicolumn{2}{|c|}{$4 Q$} \\
\hline & Estimate & t-value & Estimate & t-value & Estimate & t-value & Estimate & t-value \\
\hline Intercept & 1.9117 & $9.39^{* * *}$ & 2.9643 & $12.79^{* * *}$ & 1.4782 & $5.21^{* * *}$ & 2.7571 & $9.3^{* * *}$ \\
\hline TASET & -0.0014 & -0.15 & -0.0271 & $-2.78^{* * *}$ & 0.0077 & 0.65 & -0.0456 & $-3.73^{* * *}$ \\
\hline$L A$ & -0.0406 & $-5.53^{* * *}$ & -0.0317 & $-4.79^{* * *}$ & -0.0280 & $-4.00^{* * *}$ & -0.0137 & $-2.3^{* *}$ \\
\hline$A D$ & 0.1230 & 0.28 & 0.1791 & 0.37 & -0.0308 & -0.05 & 1.2845 & $2.01^{* *}$ \\
\hline$R D$ & 0.7519 & $4.08^{* * *}$ & 0.7719 & $4.72^{* * *}$ & 0.5695 & $3.16^{* * *}$ & 0.5941 & $3.35^{* * *}$ \\
\hline$L Q$ & 0.0039 & 1.21 & -0.0016 & -0.4 & 0.0067 & $2.15^{* *}$ & 0.0011 & 0.52 \\
\hline$B \tilde{S}$ & 0.1399 & $4.25^{* * *}$ & 0.0149 & 0.47 & 0.1718 & $4.84^{* * * *}$ & 0.1812 & $4.82^{* * *}$ \\
\hline$I N R T$ & 0.0000 & 0.06 & 0.0000 & 1.53 & 0.0000 & $2.41^{* *}$ & 0.0000 & $2.06^{* *}$ \\
\hline$\#$ of firms & \multicolumn{2}{|c|}{5,036} & \multicolumn{2}{|c|}{4,974} & \multicolumn{2}{|c|}{4,977} & \multicolumn{2}{|c|}{4,706} \\
\hline Adjusted $\mathrm{R}^{2}$ & \multicolumn{2}{|c|}{0.0243} & \multicolumn{2}{|c|}{0.0301} & \multicolumn{2}{|c|}{0.0162} & \multicolumn{2}{|c|}{0.0286} \\
\hline
\end{tabular}

Panel C: Grouping firms in terms of years in operation

\begin{tabular}{|c|c|c|c|c|c|c|c|c|}
\hline \multirow{2}{*}{$\begin{array}{c}\text { GASET } \\
\text { Variable }\end{array}$} & \multicolumn{2}{|c|}{$1 Q$} & \multicolumn{2}{|c|}{$2 Q$} & \multicolumn{2}{|c|}{ 3Q } & \multicolumn{2}{|c|}{$4 Q$} \\
\hline & Estimate & t-value & Estimate & t-value & Estimate & t-value & Estimate & t-value \\
\hline Intercept & 0.7621 & $5.75^{* * *}$ & 0.2139 & 1.27 & 1.0320 & $5.33^{* * *}$ & 3.8587 & $9.22^{* * *}$ \\
\hline TASET & 0.0221 & $4.52^{* * *}$ & 0.0513 & $7.76^{* * *}$ & 0.0305 & $4.28^{* * *}$ & -0.0686 & $-4.05^{* * *}$ \\
\hline$L A$ & -0.0070 & $-2.05^{* *}$ & -0.0117 & $-2.95^{* * *}$ & -0.0153 & $-3.46^{* * *}$ & -0.0365 & $-3.5^{* * *}$ \\
\hline$A D$ & -0.2427 & -0.72 & -1.0067 & $-2.5^{* *}$ & -0.1568 & -0.37 & 0.7007 & 0.86 \\
\hline$R D$ & 0.3747 & $2.15^{* *}$ & -0.2532 & -1.6 & 0.1553 & 1.32 & 0.3967 & 1.62 \\
\hline$L Q$ & -0.0071 & $-3.86^{* * *}$ & -0.0004 & -0.25 & 0.0054 & 2.52 & 0.0116 & $2.16^{* *}$ \\
\hline$B S$ & -0.0091 & -0.48 & 0.0347 & 1.49 & 0.0244 & 0.93 & 0.1719 & $2.62^{* * *}$ \\
\hline$I N R T$ & 0.0000 & $1.66^{* * *}$ & 0.0000 & 1.38 & 0.0000 & $2.07^{* *}$ & 0.0001 & $1.73^{* * *}$ \\
\hline \# of firms & \multicolumn{2}{|c|}{5,183} & \multicolumn{2}{|c|}{4,864} & \multicolumn{2}{|c|}{5,964} & \multicolumn{2}{|c|}{3,682} \\
\hline Adjusted $\mathrm{R}^{2}$ & \multicolumn{2}{|c|}{0.0202} & \multicolumn{2}{|c|}{0.0171} & \multicolumn{2}{|c|}{0.0117} & \multicolumn{2}{|c|}{0.0193} \\
\hline
\end{tabular}


As shown in Table 11, unlike other business performance-related variables, the labor equipment ratio affects GSALES differently for large companies and SMEs. There was no correlation for large companies. However, for SMEs, a lower labor equipment ratio or other investment in intangible assets was related to higher GSALES. The labor equipment ratio showed negative correlations with most dependent variables in Table 18, leading us to accept the flexibility hypothesis. In particular, for GSALES, this was true for SMEs only. When firms were grouped in terms of number of years in operation, for those with more years in operation, GSALES increased. However, for firms in operation less than 8 years, GSALES was adversely affected. This finding implies that flexibility of production is more important than longevity. In addition, firm size showed a negative relationship with respect to GSALES. Also, R\&D and advertising expenditure also tended to affect GSALES adversely.

Table 18. Factors affecting growth (GSALES)

Panel A. Grouping firms in terms of capital

\begin{tabular}{|c|c|c|c|c|c|c|c|c|}
\hline \multirow{2}{*}{$\begin{array}{l}\text { GSALES } \\
\text { Variable }\end{array}$} & \multicolumn{2}{|c|}{$1 Q$} & \multicolumn{2}{|c|}{$2 Q$} & \multicolumn{2}{|c|}{$3 Q$} & \multicolumn{2}{|c|}{$4 Q$} \\
\hline & Estimate & t-value & Estimate & t-value & Estimate & t-value & Estimate & t-value \\
\hline Intercept & 1.2132 & $5.19^{* * *}$ & 1.0974 & $2.16^{* *}$ & 1.5678 & $2.43^{* *}$ & 4.3639 & $10.6^{* * *}$ \\
\hline TASET & 0.0177 & $1.85^{*}$ & 0.0110 & 0.51 & 0.0127 & 0.44 & -0.1079 & $-5.97^{* * *}$ \\
\hline$L A$ & -0.0212 & $-4.54^{* * *}$ & -0.0113 & $-2.62^{* * *}$ & -0.0296 & $-4.81^{* * *}$ & -0.0127 & -1.6 \\
\hline$A D$ & -0.2622 & -0.64 & -0.4227 & -1.03 & 1.6374 & $2.61^{* * *}$ & 1.5553 & $2.3^{* *}$ \\
\hline$R D$ & 0.5420 & $3.3^{* * *}$ & 0.8021 & $5.55^{* * *}$ & 0.8289 & $4.34^{* * *}$ & 0.5875 & $3.13^{* * *}$ \\
\hline$L Q$ & 0.0042 & $2.17^{* *}$ & 0.0050 & $2.34^{* *}$ & 0.0112 & $4.13^{* * *}$ & -0.0033 & -0.77 \\
\hline$B S$ & 0.1972 & $4.92^{* * *}$ & 0.3202 & $5.51^{* * *}$ & 0.3566 & $4.25^{* * *}$ & -0.1198 & $-2.55^{* *}$ \\
\hline INRT & 0.0000 & 1.54 & 0.0000 & $3.93^{* * *}$ & 0.0001 & $3.75^{* * *}$ & 0.0002 & 2.53 \\
\hline \# of firms & \multicolumn{2}{|c|}{4,998} & \multicolumn{2}{|c|}{4,980} & \multicolumn{2}{|c|}{4,909} & \multicolumn{2}{|c|}{4,806} \\
\hline Adjusted $\mathrm{R}^{2}$ & \multicolumn{2}{|c|}{0.0169} & \multicolumn{2}{|c|}{0.0268} & \multicolumn{2}{|c|}{0.0232} & \multicolumn{2}{|c|}{0.0333} \\
\hline
\end{tabular}

Panel B. Grouping firms in terms of number of employees

\begin{tabular}{|c|c|c|c|c|c|c|c|c|}
\hline \multirow{2}{*}{$\begin{array}{l}\text { GSALES } \\
\text { Variable }\end{array}$} & \multicolumn{2}{|c|}{$1 Q$} & \multicolumn{2}{|c|}{$2 Q$} & \multicolumn{2}{|c|}{$3 Q$} & \multicolumn{2}{|c|}{$4 Q$} \\
\hline & Estimate & t-value & Estimate & t-value & Estimate & t-value & Estimate & t-value \\
\hline Intercept & 1.9117 & $9.39^{* * *}$ & 2.9643 & $12.79^{* * *}$ & 1.4782 & $5.21^{* * *}$ & 2.7571 & $9.3^{* * *}$ \\
\hline TASET & -0.0014 & -0.15 & -0.0271 & $-2.78^{* * *}$ & 0.0077 & 0.65 & -0.0456 & $-3.73^{* * *}$ \\
\hline$L A$ & -0.0406 & $-5.53^{* * *}$ & -0.0317 & $-4.79^{* * *}$ & -0.0280 & $-4.00^{* * *}$ & -0.0137 & $-2.3^{* *}$ \\
\hline$A D$ & 0.1230 & 0.28 & 0.1791 & 0.37 & -0.0308 & -0.05 & 1.2845 & $2.01^{* *}$ \\
\hline$R D$ & 0.7519 & $4.08^{* * *}$ & 0.7719 & $4.72^{* * *}$ & 0.5695 & $3.16^{* * *}$ & 0.5941 & $3.35^{* * *}$ \\
\hline$L Q$ & 0.0039 & 1.21 & -0.0016 & -0.4 & 0.0067 & $2.15^{* *}$ & 0.0011 & 0.52 \\
\hline$B S$ & 0.1399 & $4.25^{* * *}$ & 0.0149 & 0.47 & 0.1718 & $4.84^{* * *}$ & 0.1812 & $4.82^{* * *}$ \\
\hline$I N R T$ & 0.0000 & 0.06 & 0.0000 & 1.53 & 0.0000 & $2.41^{* *}$ & 0.0000 & $2.06^{* *}$ \\
\hline \# of firms & \multicolumn{2}{|c|}{5,036} & \multicolumn{2}{|c|}{4,974} & \multicolumn{2}{|c|}{4,977} & \multicolumn{2}{|c|}{4,706} \\
\hline Adjusted $\mathrm{R}^{2}$ & \multicolumn{2}{|c|}{0.0243} & \multicolumn{2}{|c|}{0.0301} & \multicolumn{2}{|c|}{0.0162} & \multicolumn{2}{|c|}{0.0286} \\
\hline
\end{tabular}

Panel C. Grouping firms in terms of years in operation

\begin{tabular}{|c|c|c|c|c|c|c|c|c|}
\hline \multirow{2}{*}{$\begin{array}{l}\text { GSALES } \\
\text { Variable }\end{array}$} & \multicolumn{2}{|c|}{ 1Q } & \multicolumn{2}{|c|}{$2 Q$} & \multicolumn{2}{|c|}{$3 \mathbf{Q}$} & \multicolumn{2}{|c|}{$4 Q$} \\
\hline & Estimate & t-value & Estimate & t-value & Estimate & t-value & Estimate & t-value \\
\hline Intercept & 0.7621 & $5.75^{* * *}$ & 0.2139 & 1.27 & 1.0320 & $5.33^{* * *}$ & $3.8587^{* * *}$ & 9.22 \\
\hline TASET & 0.0221 & $4.52^{* * *}$ & 0.0513 & $7.76^{* * *}$ & 0.0305 & $4.28^{* * *}$ & $-0.0686^{* * *}$ & -4.05 \\
\hline$L A$ & -0.0070 & $-2.05^{* *}$ & -0.0117 & $-2.95^{* * *}$ & -0.0153 & $-3.46^{* * *}$ & $-0.0365^{* * *}$ & -3.5 \\
\hline$A D$ & -0.2427 & -0.72 & -1.0067 & $-2.5^{* *}$ & -0.1568 & -0.37 & 0.7007 & 0.86 \\
\hline$R D$ & 0.3747 & $2.15^{* *}$ & -0.2532 & -1.6 & 0.1553 & 1.32 & 0.3967 & 1.62 \\
\hline$L Q$ & -0.0071 & $-3.86^{* * *}$ & -0.0004 & -0.25 & 0.0054 & 2.52 & $0.0116^{* *}$ & 2.16 \\
\hline$B \bar{S}$ & -0.0091 & -0.48 & 0.0347 & 1.49 & 0.0244 & 0.93 & $0.1719^{* * *}$ & 2.62 \\
\hline INRT & 0.0000 & $1.66^{*}$ & 0.0000 & 1.38 & 0.0000 & $2.07^{* *}$ & $0.0001^{*}$ & 1.73 \\
\hline \# of firms & \multicolumn{2}{|c|}{5,183} & \multicolumn{2}{|c|}{4,864} & \multicolumn{2}{|c|}{5,964} & \multicolumn{2}{|c|}{3,682} \\
\hline Adjusted $\mathrm{R}^{2}$ & \multicolumn{2}{|c|}{0.0202} & \multicolumn{2}{|c|}{0.0171} & \multicolumn{2}{|c|}{0.0117} & \multicolumn{2}{|c|}{0.0193} \\
\hline
\end{tabular}




\section{CONCLUSION}

The following results were obtained from our empirical analysis on externally audited companies conducted with the goal of discovering factors that can enhance competitiveness of SMEs. The factors affecting business performance showed clear differences for large vs small and medium companies. Such differences must be recognized in order to develop better policies for support of SMEs, and the focus should be on those factors that specifically affect their performance. In this study, the results demonstrated that several factors affect profitability and growth of SMEs; in fact, the results for all those except for labor productivity and productivity were opposite to those of large companies. In particular, for large companies with more than 1000 employees, economies of scale were clearly important, indicating that, the larger the company, the higher the profitability and growth. On the other hand, for SMEs, especially those ones with low amounts of capital, the relationship was opposite. The implication is that small and medium-sized companies, rather than trying to improve profitability based on economies of scale, should try to enhance performance by increasing flexibility. In practice, investment in equipment and intangible assets are all short-term expenses. Therefore, for smaller, newer SMEs, such expenses could adversely affect productivity and profitability. Also, even among SMEs, for new companies, a higher labor equipment ratio could adversely affect growth. That is, for SMEs that are smaller and newer, instead of making aggressive investments in labor and equipment, it is better to take advantage of their small scale and manage the company with flexibility. The focus should be on minimizing costs to improve profitability. However, since investment in intangible assets, with some exceptions, affects growth positively, it is also necessary to continue to invest in intangible assets from the perspective of growth rather than for short-term profitability. For older SMEs or those with large amounts of capital to enhance productivity, similar to large companies, economies of scale tend to have a positive effect. Therefore, it is necessary to determine, depending on the situation, if it is better to improve profitability or pursue growth before making investments in order to achieve the desired performance.

Types of financing and methods of support for SMEs must accord with their circumstances. For example, if funding is to be used for investment in intangible assets, even if flexibility is lost due to size, it must be provided to SMEs that can improve competitiveness. When providing funding for R\&D, due to immediate cost increases, long-term growth must be taken into account rather than profitability. Since the influence of flexibility or investment on intangible assets may vary according to the number of years in operation or firm size, these differences must also be taken into account. For financing of SMEs, the uses of funding must be understood. Instead of being used for general expenses, the results of this study reveal that funding must be used for long-term investment such as R\&D. It is also advisable to invest in areas that they may not be able to develop otherwise by themselves. In addition, for SMEs, CEO and management strategy may affect business performance (Choi et al., 2003). Instead of using a narrow performance index to assess the managerial performance of the company, as shown in Lee (2006), multiple performance indices should be utilized and considered in determining financing.

The methods used in this research have a limitation. In this analysis, factors affecting competitiveness and firm performance were analyzed and their short-term effects were studied. Of course, short-term effects accumulate to become long-term effects, which influence investment. However, as the results vary according to different factors such as the number of years in operation, the circumstances of SMEs should be considered an analysis of the longterm effects of these factors. Also, since externally audited companies require capital of 100 billion KRW and SMEs include companies with deep foundations, the results may differ when choosing SMEs that require actual support

\section{ACKNOWLEDGEMENT}

This work was supported by the Incheon National University (International Cooperative) Research Grant in 2014

\section{AUTHOR BIOGRAPHIES}

Kyung Jin Park, Associate Professor, Dept of Business Administration, Myongji University, 34 Geobukgol-ro, Seodaemun-gu, Seoul, 03688, Korea. E-mail: chichikj@mju.ac.kr

Youngtae Yoo, Assistant Professor, Dept. of Tax \& Accounting, Incheon National University, 119 Academy-ro, Yeonsu-gu, Incheon 22012, Korea. E-mail: ytae@inu.ac.kr 


\section{REFERENCES}

1Baños-Caballero S., P. J. García-Teruel \& P. Martínez-Solano. (2012). How does working capital management affect the profitability of Spanish SMEs? Small Business Economics 39(2), 517-529

Caloghiroua Y., A. Protogeroua, Y. Spanosb \& L. Papagiannakisa. (2004). Industry-Versus Firm-specific Effects on Performance: Contrasting SMEs and Large-sized Firms. European Management Journal 22(2), 231-243

Choi Y. H., J. K. Shin \& S. H. Kim. (2003). The Impact of Top Management Strategy, and Structure on Performance of Small and Medium Sized Firms. The Korean Small Business Review 25(2), 103-125

Demsetz H. (1973). Industry Structure, Market Rivalry, and Public Policy. The Journal of Law and Economics 16(1), 1-9

Fazio, G. \& D. Piacentino. (2010). A Spatial Multilevel Analysis of Italian SMEs' Productivity. Spatial Economic Analysis Volume 5(3), 299-316

García-Teruel P. J. \& P. Martínez-Solano. (2007). Effects of working capital management on SME profitability. International Journal of Managerial Finance 3(2), 164-177

Hall B. H., F. Lotti \& J. Mairesse. (2009). Innovation and productivity in SMEs: empirical evidence for Italy. Small Business Economics 33(1), 13-33

Mahmood Muhammad. (2008). Labour productivity and employment in Australian manufacturing SMEs. International Entrepreneurship and Management Journal 4(1), 51-62

Mañez J. A., M. E. Rochina-Barrachina, A. Sanchis \& J. A. Sanchis. (2013). Do process innovations boost SMEs productivity growth. Empirical Economics 44(3), 1373-1405

Mills, D. E. \& L. Schumann. (1985). Industry Structure with Fluctuating Demand. The American Economics Review 75(4), 758767

O'Regan N., A. Ghobadian \& D. Gallear. (2006). In search of the drivers of high growth in manufacturing SMEs. Technovation 26(1), 30-41

Qian G. (2002). Multinationality, product diversification, and profitability of emerging US small- and medium-sized enterprises. Journal of Business Venturing 17(6), 611-633

Pais M. A. \& P. M. Gama. (2015). Working capital management and SMEs profitability: Portuguese evidence. International Journal of Managerial Finance 11(3), 341 - 358

Ravenscraft, D. J. (1983). Structure Profit Relationship at the Line of Business and Industry Level. The Review of Economics and Statistics 65(1), 135-145

Salavou H. (2002). Profitability in market-oriented SMEs: does product innovation matter? European Journal of Innovation Management 5(3), 164-171

Song J. G. (2001). The Determinants if the Relative Advantages of Small and Large Business in Korea Manufacturing. The Korean Small Business Review 23(1), 105-128

Stephen M. \& K. Elvis. (2011). Influence of Working Capital Management on Firms Profitability: A Case of SMEs in Kenya. International Business Management 5(5), 279-286

Song J. G. (2004). An Analysis of the Determinants of the Firm's Performance in Korea. The Korean Small Business Review 26(4), 79-98

Tan W. C. M. and R. S. T. Tay. (1995). Factors Contributing to the growth of SMEs: The Singapore case. Journal of Enterprising Culture 3(2), 197-210

Tauringana V. \& G. A. Afrifa. (2013). The relative importance of working capital management and its components to SMEs' profitability. Journal of Small Business and Enterprise Development 20(3), 453-469

Lee Y. B., C. J. Shim, M. H. Kim \& D. J. Lee. (2006). The Performance and its Factors of Policy Funds in Small and medium Sized Firms. The Korean Small Business Review 28(1), 203-226

Moreno A. M. \& J. C. Casillas. (2007). High-growth SMEs versus non-high-growth SMEs: a discriminant analysis. Entrepreneurship \& Regional Development: An International Journal 19(1), 69-88

Korea Federation of SMEs. (2012) Small and Medium Business Status Index

Korea Federation of SMEs. (2012) Small and Medium Business Situation Investigation 


\section{NOTES}

